\title{
Vaccinia virus-mediated cancer immunotherapy: cancer vaccines and oncolytics
}

\author{
Zong Sheng Guo ${ }^{1,2^{*}} \mathbb{D}$, Binfeng Lu ${ }^{1,3}$, Zongbi Guo ${ }^{4}$, Esther Giehl ${ }^{1,2}$, Mathilde Feist ${ }^{1,2}$, Enyong Dai ${ }^{1,2}$, Weilin Liu ${ }^{1,2}$, \\ Walter J. Storkus ${ }^{1,3,5}$, Yukai He ${ }^{6}$, Zuqiang Liu' ${ }^{1,2}$ and David L. Bartlett ${ }^{1,2}$
}

\begin{abstract}
Cancer vaccines and oncolytic immunotherapy are promising treatment strategies with potential to provide greater clinical benefit to patients with advanced-stage cancer. In particular, recombinant vaccinia viruses (W) hold great promise as interventional agents. In this article, we first summarize the current understanding of virus biology and viral genes involved in host-virus interactions to further improve the utility of these agents in therapeutic applications. We then discuss recent findings from basic and clinical studies using $W$ as cancer vaccines and oncolytic immunotherapies. Despite encouraging results gleaned from translational studies in animal models, clinical trials implementing $W$ vectors alone as cancer vaccines have yielded largely disappointing results. However, the combination of $W$ vaccines with alternate forms of standard therapies has resulted in superior clinical efficacy. For instance, combination regimens using TG4010 (MVA-MUC1-IL2) with first-line chemotherapy in advanced-stage nonsmall cell lung cancer or combining PANVAC with docetaxel in the setting of metastatic breast cancer have clearly provided enhanced clinical benefits to patients. Another novel cancer vaccine approach is to stimulate anti-tumor immunity via STING activation in Batf3-dependent dendritic cells (DC) through the use of replication-attenuated $W$ vectors. Oncolytic Ws have now been engineered for improved safety and superior therapeutic efficacy by arming them with immune-stimulatory genes or pro-apoptotic molecules to facilitate tumor immunogenic cell death, leading to enhanced DC-mediated cross-priming of T cells recognizing tumor antigens, including neoantigens. Encouraging translational and early phase clinical results with Pexa-Vec have matured into an ongoing global phase III trial for patients with hepatocellular carcinoma. Combinatorial approaches, most notably those using immune checkpoint blockade, have produced exciting pre-clinical results and warrant the development of innovative clinical studies. Finally, we discuss major hurdles that remain in the field and offer some perspectives regarding the development of next generation $\mathrm{W}$ vectors for use as cancer therapeutics.
\end{abstract}

\section{Background}

Humankind has accumulated a rich and extensive clinical experience with vaccinia virus (VV) due to its successful use as a smallpox vaccine. Since the late 1980s, investigators have been harnessing recombinant DNA technology, to explore the utility of recombinant VV and other poxviruses as expression vectors for the purpose of active immunization in the setting of cancer and infectious disease [1]. VV vectors have been extensively

\footnotetext{
* Correspondence: guozs@upmc.edu

${ }^{1}$ UPMC Hillman Cancer Center, Pittsburgh, PA, USA

${ }^{2}$ Department of Surgery, University of Pittsburgh School of Medicine,

Pittsburgh, PA, USA

Full list of author information is available at the end of the article
}

studied in pre-clinical tumor models and in many clinical trials for treatment of patients with advanced-stage solid cancers. Despite low rates of objective clinical responses, investigators have learned many important lessons, allowing for the evolution of improved strategies for application in the future [1]. VV has also been systematically explored as an oncolytic virus $(\mathrm{OV})$ over the past 20 years. Among the three oncolytic VVs tested in cancer patients, Pexa-Vec showcases the clinical development of such an OV and is currently being evaluated in a global phase III clinical trial for patients with hepatocellular carcinoma (HCC).

(c) The Author(s). 2019 Open Access This article is distributed under the terms of the Creative Commons Attribution 4.0 International License (http://creativecommons.org/licenses/by/4.0/), which permits unrestricted use, distribution, and 
These are indeed exciting times for cancer immunotherapy, as the field is rapidly progressing, fueled by consistent evidence of therapeutic efficacy and durable clinical benefit amongst a subset of treated patients [2-4]. Cancer vaccines and oncolytic immunotherapy represent some of the most promising immunotherapy regimens. Many classic cancer vaccines have utilized non-replicating viruses as vectors to express tumor antigens and/or immune-modulatory molecules [1]. OVs function to kill cancer cells and associated stromal cells through multiple mechanisms, leading to DC-mediated activation of protective anti-tumor immunity. In 1999, Toda et al. demonstrated that an oncolytic herpes simplex virus was capable of inducing specific anti-tumor immunity via a process that they termed as an "in situ cancer vaccine" [5]. We and others have reviewed the concept of using $\mathrm{OV}$ as a unique type of cancer vaccine $[6,7]$ and the likely superior benefits that would be associated with integrating OVs into combination immunotherapies for improving objective clinical response rates $[8,9]$.

\section{Biology of vaccinia virus}

Poxviruses are comprised of two subfamilies containing at least 46 species: Chordopoxvirinae (those infecting vertebrates) and Entomopoxvirinae (those infecting insects) [10]. VV, the species of interest in this review, is a member of the orthopoxvirus genus of the Chordopoxvirinae subfamily. As smallpox vaccination became widespread throughout the world over the past 200 years, research- and clinical-centers have produced and maintained viruses in different ways, resulting in differential viral characteristics, pathogenicity and host ranges (i.e. different strains of virus). VV has a linear, double-stranded DNA genome approximately $190 \mathrm{~kb}$ in length, which encodes about 200 genes. Physically, the virus particle is the shape of a brick, averaging $270 \times$ $350 \mathrm{~nm}$ in size.

The entire VV life cycle occurs within the cytoplasm of mammalian cells (Fig. 1). Cell entry occurs by virion fusion with the host cell membrane [11]. VV contains an

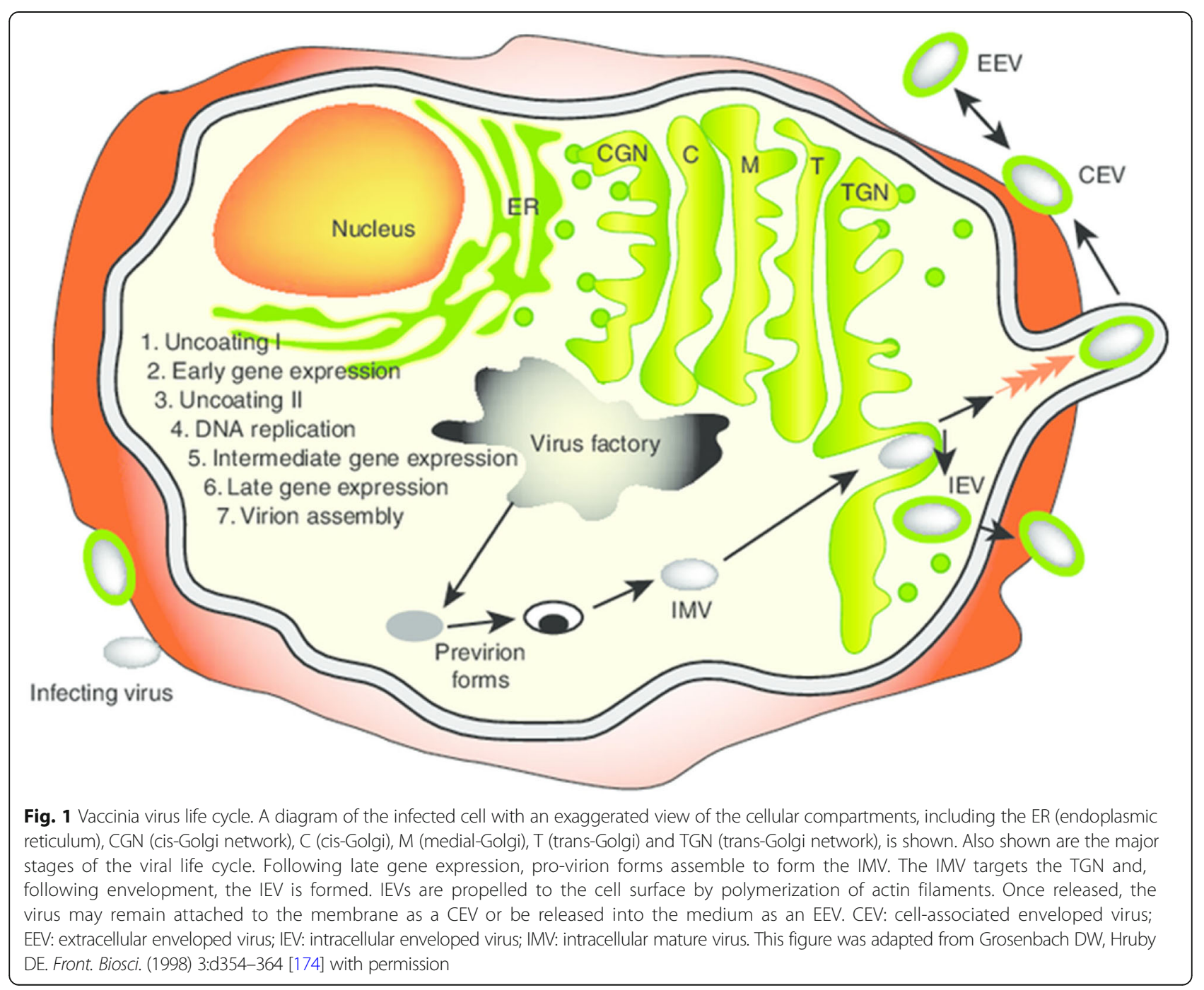


outer envelope as well as an internal membrane and incorporates enzymes required for initiation of viral transcription post-infection. Viral transcription can be classified into three stages - early, intermediate, and late - with each increment involving its own specific promoters and transcription factors [12]. In the early phase, enzymes and other components needed for the process of early transcription are contained within the viral core along with viral genomic DNA [12]. A DNAdependent RNA polymerase is also contained within the viral core, leading to the synthesis of early messenger RNA. Translation of this RNA yields early stage proteins involved in the uncoating of viral DNA, DNA replication, and transactivation of intermediate mRNA. While initial RNA transcripts can be detected within $20 \mathrm{~min}$, the entire replication cycle is complete within approximately $1 \mathrm{~h}$. VV replication and progeny assembly take place exclusively in the cytoplasm of infected cells at discrete foci in endoplasmic reticulum (ER)-enclosed cytoplasmic mini-nuclei [13], known as "poxvirus factories". VV replication utilizes the origin of DNA replication located near the end of the genome through the leading/lagging strand replication mode [14]. In this regard, VV activates cytoplasmic ATR early during infection and before genome uncoating, which promotes VV genome replication [15]. Intermediate mRNA is then expressed and encodes for late transactivators, leading to late mRNA synthesis. Late proteins include structural proteins for membrane formation and early transcription factors, which are incorporated into new progeny virus particles. The hijacking of the host translation apparatus inside the virus factories by the virus contributes to enhanced viral replication and to the suppression of host protein synthesis, thereby facilitating viral subjugation of infected cells [16]. In fact, virus induces a profound cytopathic effect soon after viral entry, as the early viral enzymes completely shut down host cell functions. Between 4 and $6 \mathrm{~h}$ after infection, host protein synthesis is almost completely inhibited, facilitating the efficient expression of viral genes and viral replication. Remarkably, approximately 10,000 copies of the viral genome are made within $12 \mathrm{~h}$ postinfection [17].

Several key viral genes, proteins, and molecular and cellular mechanisms are involved in productive viral infection, replication, virion assembly, and the spreading of progeny viruses. Viral entry into cells is mediated by an entry-fusion protein complex consisting of eight viral proteins: A16, A21, A28, G3, G9, H2, J5 and L5 [14]. All eight proteins that make up the entry-fusion complex are conserved in all poxviruses, suggesting non-redundant functions and an evolutionarily-conserved entry mechanism. VV possesses two infectious forms: the intracellular mature virus (IMV) and the extracellular enveloped virus
(EEV), also referred to as the MV and EV forms, respectively. It is intriguing to note that attachment to the cell surface differs between IMV and EEV. The IMV form contains several other proteins in its outer envelope, including A17L, A27L, and D8L [18], which likely modulate viral attachment. A27L mediates VV interaction with cell surface heparan sulfate $[19,20]$, with viral infection inhibited by up to $60 \%$ in the presence of soluble heparin [19]. The EEV form is responsible for cell-to-cell spread and longrange transmission of $\mathrm{VV}$ in vivo [21]. EEV-specific proteins are encoded by the genes A33R, A34R, A36R, A56R, B5R, and F13 L $[10,18]$.

The first stage in the formation of infectious particles is the development of viral crescents composed of lipid and viral proteins, with recent evidence suggesting the ER as the origin [22]. These crescents then coalesce into immature virus that lack infectivity. Immature virus becomes IMV by condensation of the core and processing of core proteins. IMV is transported to sites where it becomes wrapped with two additional membrane layers derived from components scavenged from the trans-Golgi network. These membranes are modified by the inclusion of virus-encoded proteins. These wrapped, intracellular, enveloped viruses traffic along microtubules to the cell surface, where the outer membrane fuses with the plasma membrane, thus exposing the viruses on the cell surface. IMV particles are transported to the cell periphery on microtubules, where they fuse with the plasma membrane to form cell-associated enveloped virus (CEV). Two intracellular enveloped virus (IEV)-specific proteins, F12 L and A36R, along with cellular microtubules (as motors), mediate IEV transport to the cell periphery [23].

Upon reaching the plasma membrane, VV switches from microtubule-dependent transport to the formation of actin tails required for cell-to-cell spread of virus [24]. This process is dependent on phosphorylation of the EEV protein A36R, a process mediated by multiple families of tyrosine kinases [24-26]. The EEV form may play a role in the rapid spread of $\mathrm{VV}$ and its wide host range. The A34R protein helps to maintain the virus particle on the cell surface. The WR strain exists almost exclusively as a cell-associated virus [27], while the IHD-J strain produces quantitatively more of the EEV form of the virus [28]. Further studies show that the A34R gene from the IHD-J strain is responsible for increased EEV production, with a codon mutation (K151E) sufficient to transfer a comet-forming phenotype to the WR virus [29]. Our recent data suggest that a single mutation, K151E, in the A34R protein results in an increase in both EEV release and total progeny virus production from infected cancer cells [30].

$\mathrm{VV}$ has evolved three intriguing mechanisms to promote viral spread. The first one is for cell-to-cell spread. 
Viral protein F11 promotes cell-to-cell spread by acting as a scaffold, using its PDZ domain to unite myosin IXa and RHOA, which inhibits RHOA signaling and ultimately promotes viral spread [31]. The other two mechanisms are for distant spread. One is the production and release of the EEV form [32], while the other is the repulsion of superinfecting virions [33]. Smith et al. recently showed that VV spreads across one cell every 75 min, four-fold faster than its replication cycle permits. The authors found that newly infected cells express two surface viral proteins (A33 and A36) that mark cells as infected and, via exploitation of cellular machinery, induce the repulsion of superinfection virions towards uninfected cells. During this process, protein B5 on the membrane of the EEV particle is required for repulsion of superinfection virions [34]. Improved strategies taking advantage of these unique mechanisms may further improve therapeutic viral spread.

In summary, genetic manipulations of the viral genome may lead us to advances in the development of next generation VV vectors for implementation in cancer therapies.

\section{Further improvements of viral vectors for use as cancer vaccines and/or OVs}

There are numerous advantages and disadvantages to the use of $\mathrm{VV}$ in cancer vaccine formulations or as oncolytic agents. Table 1 compares some of the properties of VV, herpes simplex virus (HSV), and coxsackievirus, revealing similarities and differences that impact their clinical utility. All three viruses induce immunogenic tumor cell death, which is beneficial to the development of adaptive therapeutic immunity. In terms of generating mutations in the host genome, HSV carries more risk, as it replicates in the host cell nucleus, and carries the possibility for integration into the host genome [35]. Coxsackievirus is a positive-sense single-stranded RNA virus with two weaknesses that contraindicate its use as a vector. First, it is relatively difficult to clone a gene into this viral genome. Second, the size of foreign insert DNA is very limited, with an upward limit of 300-bases permissible for stable recombinant. Indeed, the use of VV or HSV as vectors (instead of CVB3) is warranted in order to express large single transgenes or the coordinate expression of multiple transgenes.

The advantages of VV may include but are not limited to: (1). Its efficient life cycle, producing mature progeny virus in just $6 \mathrm{~h}$; (2). Its three mechanisms of viral spread, which ensure fast, efficient dissemination of the virus; (3). Its large viral genome, enabling its acceptance of large foreign DNA inserts of up to $40-\mathrm{kb}$; (4). Its lack of promoting disease in healthy humans; and (5). Extensive clinical experience and knowledge of the virus due to its use as a smallpox vaccine. On the flip side, the viral genome encodes about 200 viral genes, $50 \%$ of which have unknown functions, which provides a level of unpredictability for this virus.

Four major advances have recently been made to recombinant VVs and other poxviruses to improve their utility as cancer vaccines or OVs: 1) Further modification of the viral vectors to make them more immunogenic and thus more potent in eliciting antitumor immunity; 2) Arming the virus with genes encoding specific tumor-associated antigens (TAAs) or neo-antigens for improved induction of specific $\mathrm{T}$ cell-mediated immunity, 3) Arming them with immunostimulatory molecules to further enhance their immunogenicity, and finally, 4) Combining these vectors with systemic immunomodulatory regimens.

Table 1 A comparison of three oncolytic viruses: strength and pitfalls

\begin{tabular}{|c|c|c|c|}
\hline Virus & W & Herpes simplex virus (HSV) & $\begin{array}{l}\text { Coxsackievirus A21, B3 (CVA21 } \\
\text { and CVB3) }\end{array}$ \\
\hline Genome & dsDNA ( 180-Kb, 200 genes) & dsDNA ( 152-kb, 80 genes) & (+) ssRNA ( 7.4-Kb, one polyprotein) \\
\hline Capacity of inserted DNA & $25-40 \mathrm{~Kb}$ & $30-40 \mathrm{~Kb}$ & 300 bases for stable recombinant \\
\hline $\begin{array}{l}\text { Tumor selectivity } \\
\text { (once inside the cells) }\end{array}$ & $\begin{array}{l}\text { Pexa-Vec: selectively replicates in and } \\
\text { destroys cancer cells driven by genetic } \\
\text { pathways commonly activated in } \\
\text { cancers. }\end{array}$ & $\begin{array}{l}\text { T-VEC: two mutations make up cancer } \\
\text { selectivity with activated Ras and high } \\
\text { endogenous ribonucleotide reductase }\end{array}$ & $\begin{array}{l}\text { Aberrant signaling pathways within } \\
\text { tumor cells } \\
\text { On cell surface: CVA21: ICAM-1 } \\
\text { dependent. CVB3: CAR dependent }\end{array}$ \\
\hline Life cycle & Cytoplasm (no risk of integration) & Nucleus (more risk of integration) & Cytoplasm \\
\hline Mechanisms of cell death & Apoptosis and necroptosis (ICD) ${ }^{a}$ & Apoptosis, necrosis, and pyroptosis (ICD) & $\begin{array}{l}\text { Immunogenic apoptosis, autophagy } \\
\text { (ICD) }\end{array}$ \\
\hline Immunogenicity & High & High & High \\
\hline Transgene expression & High & High & High \\
\hline Clinical trial stage & Phase III for liver cancer & T-VEC approved for melanoma & $\begin{array}{l}\text { Phase II study in advanced } \\
\text { melanoma (CVA21) }\end{array}$ \\
\hline
\end{tabular}

${ }^{\mathrm{a}} / C D$ immunogenic cell death 
1). Further modification of VV viral vectors for improved immunogenicity.

The key viral genes to be manipulated are those whose products interact with the host leading to altered immunogenicity [36]. In Table 2, we list about 20 virusencoded genes whose products modulate innate and adaptive immunity. These represent cogent targets for genetic manipulation to enhance viral vector immunogenicity. Since a comprehensive discussion for all of these molecules is not possible in this forum, we have chosen to discuss a limited number of "high-priority" targets.

Products of several viral genes inhibit the NF- $\mathrm{kB}$ signaling pathways via a range of mechanisms. These genes include A49, A52R, B15R, K1L, K7R, and possibly others [37-40]. Esteban and colleagues have studied three genes, A52, B15, and K7. These gene products act coordinately to inhibit NF- $\mathrm{kB}$. After infection of a $\mathrm{VV}$ incorporating a deletion of these three genes, NF$\mathrm{KB}$ is activated, leading to the production of pro-inflammatory cytokine/chemokines which recruit neutrophils $(\mathrm{N} \alpha$ and $\mathrm{N} \beta$ ), a sub-type of antigen-presenting cells (APCs), into sites of infection. This subsequently sponsors enhanced $\mathrm{T}$ cell responses against both the virus and any vector-encoded antigens [37,38]. Shisler and colleagues showed that VV with a deletion of the K1L gene is less pathogenic, less immunogenic, and less capable of promoting immune cell infiltration in an intradermal model, yet it was still competent to elicit protective immunity [39]. In another study, the authors deleted the viral genes A44L, A46R, and C12L from the MVA genome. This modified MVA showed enhanced immunogenicity via a mechanism involving innate immune cell activation, leading to corollary generation of specific T-cell responses [41]. VV A49 protein targets the cellular E3 ubiquitin ligase $\beta-\operatorname{TrCP}$, with the latter responsible for the ubiquitylation and consequent proteasome-mediated degradation of I $\mathrm{K} B \alpha$, resulting in the release of the NF- $\kappa B$ heterodimer. The enzyme ubiquitylates multiple cellular substrates, including the transcriptional activator $\beta$-catenin. In a recent study, expression of viral A49 was shown to cause an accumulation of $\beta$-catenin and $\beta$-TrCP-dependent activation of Wnt signaling [40].

Another class of interesting targets are the viral genes involved in cell death $[42,43]$. Previously, we showed that deletion of the Spi-2/Spi-1 genes from VV renders it highly-attenuated in normal tissue, yet it retains replication competence in cancer cells and functions as a potent oncolytic VV [44]. At the same time, Yilma and colleagues showed that the same deletion of genes, with a coordinate enforcement of IFN- $\gamma$ expression, leads to improved VV induction of immune responses in the absence of detectable replication in normal tissues. As a consequence, such vectors may prove to be extremely safe and effective when applied as vaccines against cancer and other diseases [45]. While not all types of cancer cell death are considered immunostimulatory, the concept of "immunogenic cell death" has been recently advanced [46]. Necroptosis is one of the few types of cell death that classifies as immunogenic cell death. In this regard, it is highly interesting to note that the immune evasion protein E3 encoded by VV inhibits DAI-dependent necroptosis. VV with a deletion of the Zalpha domain of E3 induced rapid RIPK3-dependent cell death in IFN-treated L929 cells [47]. This virus is attenuated in vivo.

2). Induction of systemic antitumor immunity via STING and Batf3-dependent dendritic cells.

Mammalian cells have evolved defense mechanisms against infection, with rapid detection of microbial agents. The STING (stimulator of interferon genes)-controlled innate immune pathway mediates cytosolic DNA-induced signaling events. The knowledge we have gained through this particular signaling pathway may open new ways to induce novel immunization and therapeutic strategies to treat cancer [48].

In this regard, a recent study on inactivated VV raised some intriguing notions relevant to the design of prospective cancer vaccine strategies. The MVA strain of VV is an attenuated poxvirus that has been engineered for use as a cancer vaccine. It triggers type I IFN production in conventional dendritic cells (cDCs) via a cGAS/STING-mediated cytosolic DNA-sensing pathway [49]. When cDCs were infected with heat- or ultraviolet-inactivated MVA, it led to higher levels of interferon production versus MVA alone as a consequence of STING activation [50]. The injection of inactivated MVA directly into tumors led to the generation of therapeutic adaptive antitumor responses in murine melanoma and colon cancer models. In addition, the authors suggest that both cytosolic DNA sensing and Batf3-dependent $\mathrm{CD} 103^{+} / \mathrm{CD} \alpha^{+}$ DCs are essential to the antitumor efficacy of this mode of cancer immunotherapy [50]. Another group also showed that STING agonist-formulated cancer vaccines can cure established tumors refractory to PD-1 blockade [51].

3). Arming VV with genes for enhanced immunogenicity, including tumor antigens and costimulatory molecules.

To improve their immunogenicity, investigators have armed viral vectors with genes encoding specific TAAs, neoantigens and/or immunostimulatory molecules. Several groups have generated recombinant VVs expressing various cytokines and used them as cancer vaccines in the 1990s. These early studies strongly support the 
Table 2 Vaccinia virus (W) encodes multiple genes whose products modulate immune responses

\begin{tabular}{|c|c|c|c|}
\hline Viral genes & Key function & Relevant findings & References \\
\hline A41L & chemokine binding protein & Deletion of A41L enhances W immunogenicity and vaccine efficacy & [175] \\
\hline A44L & 3beta-HSD enzyme (v3beta-HSD) & A44L promotes steroid synthesis & {$[41,176]$} \\
\hline A46R & TLR inhibitor and putative IL-1 antagonist & A46R is an inhibitor of the TLR4 signaling pathway & [41] \\
\hline A49 & Triggers Wnt signaling & $\begin{array}{l}\text { A49 targets } \beta \text {-TrCP and thus affects multiple cellular pathways, including the } \\
\text { NF-KB and Wnt signaling cascades }\end{array}$ & [40] \\
\hline A52R & Putative inhibitor of TLR signaling & A52R targets Toll-like receptor signaling complexes to suppress host defense & [38] \\
\hline A53R & Soluble TNF receptor & $\begin{array}{l}\text { The gene deleted virus retains high immunogenicity but replication is } \\
\text { attenuated }\end{array}$ & [177] \\
\hline B5R & Inhibits complement & $\begin{array}{l}\text { Anti-B5 (EV protein) antibody-directed cell lysis via complement is a powerful } \\
\text { mechanism for clearance of infected cells }\end{array}$ & [148] \\
\hline B8R & IFN- $\gamma$ soluble receptor & B8R is a type II IFN binding protein & {$[36,178]$} \\
\hline B13R (SPI-2) & Inhibits IL-1 $\beta$ converting enzyme & $\begin{array}{l}\text { B13R is a nonessential immune-modulating gene that has antiapoptotic and } \\
\text { anti-inflammatory properties with sequence homology to serine protease } \\
\text { inhibitors (serpins) }\end{array}$ & [179] \\
\hline B15R & IL-1 $\beta$ soluble receptor & $\begin{array}{l}\text { Deletion led to increased dendritic cell, natural killer cell, and neutrophil } \\
\text { migration, as well as chemokine/cytokine expression }\end{array}$ & {$[36,38]$} \\
\hline B18R & IFN- $\alpha / \beta$ soluble receptor & $\begin{array}{l}\text { B18R encodes a secreted decoy receptor with a broad antagonizing effect } \\
\text { against type I IFNs. It is good for viral replication }\end{array}$ & [180] \\
\hline C3L (VCP) & Complement control protein (VCP) & VCP modulates adaptive immune responses during infection & {$[181,182]$} \\
\hline C6 & $\begin{array}{l}\text { Binds to STA2 and inhibits type I IFN } \\
\text { signaling }\end{array}$ & $\begin{array}{l}\text { C6 is a dual function protein that inhibits the cellular responses to type I IFNs } \\
\text { and as an inhibitor of IRF-3 activation }\end{array}$ & [183] \\
\hline$C 7 L$ & $\begin{array}{l}\text { Antagonizes IRF1-induced antiviral } \\
\text { activities }\end{array}$ & C7L inhibits antiviral activities induced by Type I interferons & {$[184,185]$} \\
\hline $\mathrm{C} 12 \mathrm{~L}$ & Binds and inhibits IL-18 & $\begin{array}{l}\mathrm{C} 12 \mathrm{~L} \text { promotes virulence by reducing gamma interferon production and } \\
\text { natural killer and T-cell activity }\end{array}$ & {$[41,186]$} \\
\hline E3L & Binds dsRNA to block PKR activation & E3 protein prevents the antiviral action of ISG15 & [187] \\
\hline F1L & Inhibits cytochrome C & F1L promotes virulence by inhibiting inflammasome activation & [188] \\
\hline $\mathrm{K} 1 \mathrm{~L}$ & Inhibits NF-kB activation & $\begin{array}{l}\text { K1L supports viral replication in human cells. Deletion of the gene led to a } \\
\text { virus that is less pathogenic due to muted innate immune responses, yet still } \\
\text { elicits protective immunity }\end{array}$ & [39] \\
\hline K3L & $\begin{array}{l}\text { The dsRNA-activated protein kinase (PKR) is } \\
\text { inhibited by this pseudosubstrate inhibitor }\end{array}$ & $\mathrm{K} 3 \mathrm{~L}$ prevents phosphorylation of e1F2a & {$[189,190]$} \\
\hline K7R & $\begin{array}{l}\text { Promotes histone methylation associated } \\
\text { with heterochromatin association }\end{array}$ & $\begin{array}{l}\text { K7R is a virulence gene; it inhibits the NF-KB pathway and thus the migration } \\
\text { of neutrophil cells. It affects the acute immune response }\end{array}$ & $\begin{array}{l}{[37,38,191,} \\
192]\end{array}$ \\
\hline M1L & Associates with apoptosome & $\begin{array}{l}\text { The current model is that } \mathrm{M} 1 \mathrm{~L} \text { associates with and allows the formation of } \\
\text { the apoptosome, but prevents apoptotic functions of the apoptosome }\end{array}$ & [193] \\
\hline $\mathrm{N} 1 \mathrm{~L}$ & Inhibits NF-kB & $\mathrm{N} 1 \mathrm{~L}$ is a Bcl-2-like anti-apoptotic protein. It inhibits the NK cell response & [194] \\
\hline
\end{tabular}

Due to the limitation of the number of references that can be cited for this journal, not all relevant papers can be listed

concept that VVs expressing a tumor antigen and a Th1-stimulatory cytokine function as potent cancer vaccines, leading to the translation of these approaches into the clinic for the treatment of cancer patients.

One of the key issues in cancer vaccines has been how to most effectively enhance the inherently-weak immunogenicity of tumor-associated antigens (TAAs) in the face of intrinsic viral proteins that are highly-immunogenic. When provoking an immune response using viral vectors, weaker epitopes derived from TAAs may be ignored by the adaptive immune response based on a biased focus on xenogeneic viral proteins [52]. This dichotomous response needs to be overcome in order for viral vectors to be optimally exploited in effective cancer vaccines. A first strategy to correct this imbalance in the immune response is to limit immune responses to the viral antigens while boosting the immune response to tumor antigens by benefiting from lessons learned about viral pathogenicity. Many viruses have acquired inhibitors that target essential stages of the MHC class I antigen presentation pathway. For example, ICP47 encoded by HSV strongly downregulates MHC class I antigen-restricted presentation by blocking the ability of transporter associated with antigen processing (TAP) proteins from conveying peptides into the ER for loading into nascent MHC class I complexes, thus limiting $\mathrm{CD}^{+} \mathrm{T}$ cell recognition of infected target 
cells. In one strategy [53], the authors developed VVs expressing either ICP47 alone or together with an ER-targeted Melan-A/MART- $1_{27-35}$ peptide epitope and used them to infect APCs. Infected APCs were defective in their ability to present TAP-dependent MHC class I-restricted viral epitopes to $\mathrm{CD}^{+}{ }^{+}$T-cells even though HLA class I molecules were expressed, as a result of ICP47dependent suppression of molecules important for aggregate TCR signaling (such as CD80, CD44, and MHC class II). However, a significantly enhanced CTL response can be detected in cultures co-stimulated with rVV-MUS12 expressing an ER-targeted (TAP-independent) tumor epitope, an approach suitable for translation as a cancer immunotherapy [53].

Significant attention has been devoted to the engineering of $\mathrm{VV}$ to encode immune costimulatory molecules, as at least two signals are required for the productive activation of naive $\mathrm{T}$ cells by antigen-bearing target (stimulator) cells: an antigen-specific signal (signal 1) delivered through the T-cell receptor, and a costimulatory signal delivered through the T-cell surface molecule CD28 (signal 2). In 1995, Schlom and others showed that a mixture of two VVs, one expressing a tumor antigen CEA and the other expressing co-stimulatory molecule B7.1 ( $\mathrm{rV}-\mathrm{CEA}$ and $\mathrm{rV}-\mathrm{B} 7)$, led to not only to the generation of optimal CEA-specific $\mathrm{T}$ cell responses, but also to the prevention of $\mathrm{CEA}^{+}$tumor establishment in mice [54]. This same team of investigators then designed poxvirus vectors encoding a TRIad of COstimulatory Molecules (B7-1/ICAM/LFA-3, termed TRICOM). They showed that these vectors induced a more robust activation of $\mathrm{T}$ cells when compared to cells infected with homologous virus encoding any one or two of these costimulatory molecules [55]. This study had broad implications in vaccine design/development and led to the performance of several clinical trials that will be discussed in greater detail later in this article.

A different regimen to improve the immunogenicity of TAAs is to apply a heterologous prime-boost regimen in cancer vaccines. By using two "mis-matched" poxviruses, PANVAC ${ }^{\mathrm{TM}}-\mathrm{VF}$ combines MVA and fowlpox viral vectors, expressing the two human antigens CEA and MUC1 and TRICOM costimulatory molecules in both vectors in order to elicit superior tumor antigen-specific immune responses [56].

Cerullo and others have recently developed a personalized cancer vaccine platform implementing clinically-relevant oncolytic enveloped viruses that can drive the expansion of responses against tumor antigens. By physically attaching tumor antigen-derived peptides onto the viral envelope of VV and HSV-1, the authors were able to induce strong $\mathrm{T}$ cell-specific immune responses. They demonstrated that OVA SIINFEKL-peptide-coated viruses and gp100-Trp2-peptide-coated viruses, respectively, promoted therapeutic $\mathrm{CD} 8^{+} \mathrm{T}$ cell responses against B16. OVA and B16-F10 melanomas in mice [57].

\section{4). Combination with alternate immunotherapy approaches, including immune checkpoint blockade.}

To bolster the immunostimulatory capacity of VV over the past several years, many have chosen to combine virus administration with agonists of immune co-stimulatory molecules or antagonists of immune co-inhibitory molecules (i.e. checkpoint blockade). For instance, vaccination with VV expressing a costimulatory molecule 4-1BBL (rV-4-1BBL) combined with host lymphodepletion (to remove regulatory cells and provide "space" for homeostatic $\mathrm{T}$ cell expansion) led to enhanced therapeutic activity versus vaccination with $\mathrm{VV}$ alone [58].

TG4010 is a MVA expressing human mucin1 (MUC1) and IL-2. Preclinical combination immunotherapy studies have been performed to further improve its efficacy. Sequential administration of a MVA-MUC1 cancer vaccine and the TLR9 ligand, Litenimod, improved local immune defense against tumors [59]. In another study, first MVA$\beta G a l$ and MVA-MUC1 treatments were used to treat mice with established CT26 colon carcinomas. Treatment with MVA vectors led to the accumulation of $\mathrm{CD} 3{ }^{\mathrm{dim}} \mathrm{CD} 8^{\text {dim }} \mathrm{T}$ cells, with two subpopulations characterized as short-lived effector cells and early effector cells (EECs) secreting IFNy and granzyme B, and translocating CD107a to the cell surface (as a surrogate to lytic granule release) upon antigenspecific peptide stimulation. However, EECs were characterized with high expression levels of the immune checkpoint molecule PD-1. In addition, tumor growth in the diseased lung correlated with $\mathrm{PD}^{+}{ }^{+}$Treg cells that was partially reduced after TG4010 treatment. In the late stages of disease, PD-L1 was detected on cancer cells and immune cells, including $\mathrm{CD}^{+} \mathrm{T}$ cells (including Treg cells), $\mathrm{CD}^{+} \mathrm{CD}^{+}$and $\mathrm{CD} 3^{\mathrm{dim}} \mathrm{CD} 8{ }^{\text {dim }} \mathrm{T}$ cells, natural killer (NK) cells, myeloid-derived suppressor cells, and alveolar macrophages. When PD-1 blockade using specific antagonist antibodies was applied several days after TG4010 treatment, therapeutic benefits associated with viral therapy were enhanced [60]. In a third study, MVA-BN-HER2 poxvirusbased active immunotherapy administered alone or in combination with CTLA-4 checkpoint blockade was investigated in the treatment of CT26-HER-2 lung metastases in mice. MVA-BN-HER2 immunotherapy significantly improved median overall survival. However, when the virus was combined with immune checkpoint blockade, therapeutic benefits were dramatically improved [61]. These data support ongoing clinical evaluation of TG4010 immunotherapy in combination with nivolumab (anti-PD1) or other combinations of VV-based cancer vaccine plus immune checkpoint blockade. 


\section{Clinical studies of VV as cancer vaccines}

The utility of VV and other poxviruses (mostly MVA and fowl poxvirus) as vehicles for cancer vaccines have been actively investigated over the last 30 years. Representative successful clinical studies are listed in Table 3. In the 1980 s and 1990s, investigators explored the concept of using wild-type vaccinia-infected melanoma cell lysates for cancer vaccines. In 1995, a phase III, randomized, double-blind multi-institutional trial of wild-type vaccinia-infected melanoma cell lysates-active specific immunotherapy for patients with stage II melanoma showed no difference in disease-free interval or overall survival when compared to naked VV delivery [62]. As a consequence of such findings, interest in such approaches has faded, but the birth of recombinant DNA technology has since revived the use of VV recombinants as cancer vaccines. Mastrangelo et al. conducted the first clinical trial using a recombinant VV expressing GM-CSF in melanoma patients and published their results in 1999 [63]. Later, a phase I/II trial for melanoma patients was conducted using recombinant VV expressing ER-targeted HLA-A0201-restricted melan-A/MART$1_{27-35}$, gp $100_{280-288}$, tyrosinase ${ }_{1-9}$ epitopes together with CD80 and CD86 proteins [64]. In this case, only weak anti-tumor immune responses were observed in most patients. Interestingly, when a VV vector coordinately expressing multiple antigen epitopes and two co-stimulatory molecules B7.1 and B7.2 in the context of systemic GM-CSF was administered to melanoma patients, specific CTLs against melanoma-associated antigens were rapidly induced in vivo [65]. In 2005, Kaufman, Marincola and others treated melanoma patients with a VV vector expressing B7.1. A standard two-dose-escalation phase I trial was conducted in 12 patients. The approach was well-tolerated, with direct injection of B7.1-expressing VV into melanoma lesions resulting in the development of both local and systemic immunity in association with objective clinical responses. Increased frequencies of gp100and MART-1-specific $\mathrm{CD} 8^{+} \mathrm{T}$ cells were identified in patient peripheral blood in ELISPOT assays [66]. Similarly, VV expressing the TRICOM (rV-TRICOM) was used to treat 13 patients with metastatic melanoma. Vaccination was well-tolerated, with only low-grade injection site reactions associated with mild fatigue and myalgia observed. Overall, there was a $31 \%$ objective clinical response, with one patient achieving a durable complete response for 22 months [67].

More advanced clinical studies have been performed over the past decade. Four sets of phase I-III clinical studies (with phase III trials performed in two cases) have been completed in cancer patients, advancing the clinical utility of MVA-5 T4, rV-PSA, TG4010 and PANVAC.

Table 3 Recombinant vaccinia virus (W) vectors as cancer vaccines: representative clinical studies

\begin{tabular}{|c|c|c|c|c|c|c|}
\hline Name & $\begin{array}{l}\text { W strains or } \\
\text { other poxvirus }\end{array}$ & TAA & $\begin{array}{l}\text { Immunostimulatory } \\
\text { gene or agents }\end{array}$ & $\begin{array}{l}\text { Clinical trial stage } \\
\text { and type of cancer }\end{array}$ & $\begin{array}{l}\text { Immunological responses and clinical } \\
\text { outcomes }\end{array}$ & References \\
\hline Trovax & MVA & $5 T 4$ & $\begin{array}{l}\text { A variety of agents } \\
\text { (such as IL-2, IFN-a, } \\
\text { sunitinib) }\end{array}$ & $\begin{array}{l}\text { Phases II and III } \\
(n=733) \\
\text { Metastatic renal } \\
\text { cancer }\end{array}$ & $\begin{array}{l}\text { (1). Patients with good prognosis } \\
\text { receiving vaccine + IL-2 had improved } \\
\text { overall survival when compared to IL-2 } \\
\text { alone. (2). Association between } 5 \text { T4- } \\
\text { specific (but not MVA) antibody } \\
\text { responses and enhanced survival. }\end{array}$ & {$[73,195]$} \\
\hline $\begin{array}{l}\text { W with } \mathrm{A} 0201- \\
\text { restricted epitopes }\end{array}$ & MVA & $\begin{array}{l}\text { Epitopes from } \\
\text { gp100, MART- } \\
2 \text { \& tyrosinase }\end{array}$ & $\begin{array}{l}\text { B7.1 and B7.2 } \\
\text { (CD80 and CD86) }\end{array}$ & $\begin{array}{l}\text { Phase I, II } \\
\text { Melanoma }\end{array}$ & $\begin{array}{l}\text { Direct injection into lymph node, or } \\
\text { given as a prime followed by peptide } \\
\text { boosting; both gave antigen-specific } \\
\mathrm{CD} 8^{+} \mathrm{T} \text { cell responses. No overall } \\
\text { survival benefit. }\end{array}$ & {$[64,196]$} \\
\hline $\begin{array}{l}\text { TG4010 } \\
+ \text { chemo }\end{array}$ & MVA & MUC1 & IL-2 & $\begin{array}{l}\text { Phase } 2 \mathrm{~b} \\
\text { Non-small cell lung } \\
\text { cancer }\end{array}$ & $\begin{array}{l}\text { TG4010 plus chemotherapy seems to } \\
\text { improve progression-free survival relative } \\
\text { to placebo plus chemotherapy. Because } \\
\text { the primary endpoint was met, the trial } \\
\text { will continue into phase III. }\end{array}$ & {$[82]$} \\
\hline $\begin{array}{l}\text { MVA-brachyury- } \\
\text { TRICOM }\end{array}$ & MVA & Brachyury & $\begin{array}{l}\text { TRICOM [B7.1, } \\
\text { ICAM-1, LFA3] }\end{array}$ & $\begin{array}{l}\text { Phase I }(n=38) \\
\text { Advanced cancer } \\
\text { patients }\end{array}$ & $\begin{array}{l}\text { Brachyury-specific T-cell responses } \\
\text { were observed at all dose levels and } \\
\text { in most patients. }\end{array}$ & [197] \\
\hline PROSTVAC & $\begin{array}{l}\text { W prime and } \\
\text { fowlpox boost }\end{array}$ & PSA & $\begin{array}{l}\text { TRICOM [B7.1, } \\
\text { ICAM-1, LFA3] }\end{array}$ & $\begin{array}{l}\text { Phase II } \\
\text { Prostate cancer }\end{array}$ & $\begin{array}{l}\text { Increased PSA-specific CTL responses, } \\
\text { particularly with GM-CSF or IL-2. In } \\
\text { prostate cancer, an increase in } \\
\text { progression-free survival } \\
\text { was observed. }\end{array}$ & {$[78,79]$} \\
\hline $\begin{array}{l}\text { PANVAC } \\
+ \text { chemo } \\
\text { (docetaxel) }\end{array}$ & $\begin{array}{l}\text { PANVAC (W } \\
\text { and fowlpox) }\end{array}$ & $\begin{array}{l}\text { CEA and } \\
\text { MUC1 }\end{array}$ & $\begin{array}{l}\text { Just PANVAC or } \\
\text { none (chemo } \\
\text { alone) }\end{array}$ & $\begin{array}{l}\text { Phase } \|(n=48) \\
\text { patients with } \\
\text { metastatic breast } \\
\text { cancer }\end{array}$ & $\begin{array}{l}\text { Combination of PANVAC with docetaxel } \\
\text { provides a clinical benefit. The median } \\
\text { progression-free survival was } 7.9 \text { months } \\
\text { in the combination group vs. } 3.9 \text { months } \\
\text { in the chemo group. }\end{array}$ & [86] \\
\hline
\end{tabular}


In the first set of trials, an MVA encoding the tumor antigen 5 T4 (MVA-5 T4, termed TroVax) was used as a vaccine against cancers expressing this antigen. The human oncofetal antigen $5 \mathrm{~T} 4$ (h5 T4) is a transmembrane glycoprotein overexpressed by a wide spectrum of cancers, including colorectal, ovarian and gastric carcinomas, but with only limited expression in normal tissues. Preclinical studies supported the effectiveness of MVA-5 T4 in a range of tumor models [68]. The first two trials were conducted in colorectal cancer patients, either used alone or in conjunction with chemotherapy. The first trial showed that vaccination with TroVax was safe. Specific immune responses against 5 T4 were induced in treated patients, and anti-5 T4 antibody responses were found to correlate with evidence of disease control [69]. When co-administered with chemotherapy, TroVax induced robust immune responses. Not too surprisingly, 5 T4 (tumor)-specific immune responses, but not MVA (viral)-specific immune responses, were found to correlate with clinical benefit [70].

In patients with metastatic renal cell carcinoma, vaccination with TroVax did not improve objective response rates vs high-dose IL-2 monotherapy, but vaccination resulted in disease stabilization in association with an increased ratio of 5 T4-specific T effector cell-to-Treg cells [71]. In a similar phase II trial with TroVax alone or administered in combination with IFN-alpha, treatments were well-tolerated in all patients. Despite high frequencies of $5 \mathrm{~T} 4$-specific $\mathrm{T}$ cells being developed in patients post-treatment, no objective clinical benefit was observed in this study [72]. In 2010, a randomized, doubleblind, placebo-controlled, phase III study for vaccination of metastatic renal cancer patients with MVA-5 T4 was completed. In this study, 733 cancer patients (365 MVA-5 T4 and 368 placebo) were recruited. Between the two arms, no significant difference in the incidence of adverse events, serious adverse events or overall survival was observed. In a subset of patients, however, the magnitude of 5 T4-specific antibody responses induced by the vaccine was found to be associated with extended patient survival [73].

A series of clinical studies in advanced-stage prostate cancer patients have been performed using MVA encoding human prostate-specific antigen (rV-PSA). The first phase I trial was completed in 2000, with rV-PSA found to be safe and capable of eliciting specific T-cell responses against PSA and extended time-to-progression in a minority of treated patients [74]. In 2002, this vaccine was applied in a phase I trial in patients with metastatic androgen-independent prostate cancer, with some patients developing expansions in their PSA-specific T cell populations in peripheral blood after vaccination [75]. In 2006, Kaufman led a Cooperative Oncology
Group sponsored phase II study using a prime/boost vaccine strategy implementing VV and fowlpox virus expressing human PSA. This regimen was well-tolerated, with a significant percentage of patients remaining free of detectable (serum) PSA and clinical progression after 19 months of follow-up. Nearly half of treated patients demonstrated evidence of vaccine-induced anti-PSA T cell responses [76]. Based on this substantial foundation, a new study was designed to improve the vaccines by using both VV and fowlpox vectors coordinately expressing TRICOM and PSA antigen. This phase I study demonstrated that vaccination with PROSTVAC-V and PROSTVAC-F combined with TRICOM is both well-tolerated and competent to promote specific immune response after vaccination with VV [77]. Furthermore, in a phase III trial using the same regimen of two vectors expressing four genes (TRICOM and PSA), the authors examined patient overall survival and immunological/ prognostic factors associated with overall survival benefit in the setting of metastatic castrate-resistant prostate cancer. PROSTVAC-VF-based immunotherapy was fond safe and effective in reducing the patient death rate by $44 \%$, leading to an 8.5-month improvement in median overall survival [78]. Finally, the authors concluded that patients developing strong PSA-specific T-cell responses were more likely to live longer [79].

The vaccine TG4010, an MVA vector expressing MUC1 and IL-2, has been evaluated in 2 randomized clinical trials in combination with first-line chemotherapy for treatment of patients with advanced-stage non-small-cell lung cancer $[80,81]$. The combination was found safe and effective in improving progression-free survival at 6 months and the proportion of patients achieving clinical responses. In a recent clinical study, Quoix et al. reported their results for the Phase $2 \mathrm{~b}$ portion of a randomized, double-blind, placebo-controlled phase $2 / \mathrm{b} / 3$ trial, supporting the conclusion that TG4010 plus chemotherapy likely improves the progression-free survival of patients when compared to treatment with a placebo plus chemotherapy. This trial is being continued into a phase III study, as the primary endpoint had been met [82].

The fourth regimen (PANVAC ${ }^{\mathrm{mm}}-\mathrm{VF}$ ) combines MVA and fowlpox viral vectors, with each virus co-expressing the two antigens CEA and MUC1, in addition to TRICOM costimulatory molecules [56]. This prime-boost regimen has now been evaluated in three clinical trials for patients with advanced-stage carcinomas, including those of the breast, ovary and pancreas. Although TAAspecific immune responses were generated in some patients, minimal objective clinical responses were observed [83-85]. More encouraging data were obtained in a clinical trial of combined treatment with PANVAC and docetaxel in metastatic breast cancer patients, where clinical benefits were noted [86]. 
What have we learned from these vaccine clinical trials using VV and fowl poxvirus-based vectors expressing cancer-associated antigens? First, all the vaccine-targeted antigens (CEA, PSA, or 5 T4) represent non-mutated sequences, which have typically exhibited low immunogenicity, linked to weak immune responses or to immune tolerance. It's perhaps then not surprising that we've typically witnessed weak anti-tumor immune responses at best amongst treated patients using these modalities. Recent studies have strongly suggested that mutated tumor neo-antigens are appreciably more immunogenic and that immune recognition of neo-antigens is a major factor in the bio-efficacy of immunotherapies in the clinical arena [87]. A recent study identified neoantigens with unique potential to serve as targets for $\mathrm{T}$ cell recognition in patients with pancreatic ductal adenocarcinoma. Notably, the authors considered neoantigen "quality" as a biomarker for immunogenic tumors that may guide the application of targeted immunotherapies [88]. Indeed, the recent success of personalized cancer vaccines appears to depend on immune targeting of verified neo-antigens from individual cancer patients [89, 90]. One most recent breakthrough study shows that noncoding regions are the main source of targetable tumor-specific antigens [91]. As a consequence, it would be expected that future trials will incorporate neo-antigen-expressing poxvirus vectors. Second, the heterologous prime-boost regimen remains a well-justified vaccine approach, despite findings that treatment with PANVAC-VF failed to yield objective clinical benefit, potentially suggesting larger rate-limiting issues for other aspects of the treatment (such as the targeting of only weak, self-antigens). Third, in many vaccine studies in the settings of infectious disease and cancer, investigators have selected multigenic viral vectors for implementations based on suppositions of higher potency and improved efficacy [92-94]. In this context, it would be logical to construct therapeutic VV vectors expressing fusion gene products containing multiple $\mathrm{T}$ cell epitopes derived from multiple tumor-associated antigens to expand a broad anti-tumor $\mathrm{T}$ cell repertoire capable of providing improved treatment benefit. Fourth, as we now know, the immunosuppressive tumor microenvironment (TME) plays a major role in legislating the outcome of immunotherapy [95]. If a patient presents with an immunologically 'cold' tumor, then circulating (vaccine-induced) $\mathrm{T}$ cells and other pro-inflammatory immune cells would be challenged to traffic into tumor sites; whereas, if the patient presents with a 'hot' tumor, immune checkpoint molecules may prevent the sustained functionality of anti-tumor T cells [96]. As we will discuss later in this article, OVs may be particularly well suited to inflame the TME and to convert immunologically 'cold' tumors into 'hot' [97, 98]. In his light, we may consider using replicating VVs as cancer vaccines. Finally, the highly immunosuppressive TME expresses multiple immune co-inhibitory molecules, such as PD-1/PD-L1, CTLA-4/ CD80, and BTLA/HVEM [99]. Therefore, in the future, a successful cancer vaccine regimen would be expected to include one or more checkpoint antagonists to sustain or expand the pro-inflammatory TME [100].

\section{VV for oncolytic immunotherapy}

We and Fodor's group were the first to explore the use of genetically-engineered $\mathrm{VV}$ as an $\mathrm{OV}$, with research papers published in 1999 and 2000 [101, 102]. During the last 20 years, investigators have created a variety of oncolytic VVs for preclinical studies [103] (Table 4).

\section{Further genetic engineering of $\mathrm{OV}$}

Manipulations were designed to achieve a higher degree of tumor-selectivity, better efficiency of vector delivery to the tumor, enhanced therapeutic efficacy, and minimized toxicity. The first genetically engineered version of oncolytic VV involved the deletion of the thymidine kinase ( $t$ k) gene alone $[101,102]$. Parato et al. demonstrated that the $t k$-deleted JX-594 (Pexa-Vec) virus selectively replicates in and destroys cancer cells [104]. We have shown that vvDD, an oncolytic VV with a dual deletion of viral genes encoding $t k$ and vaccinia growth factor $(v g f)$, is highly tumor-selective [105]. Based on the hypothesis that cancer cells often overexpress multiple anti-apoptotic proteins, and are thus more resistant to apoptosis, we deleted two anti-apoptotic viral genes, SPI-1 and SPI-2, resulting in a highly tumor-selective virus (vSP) that retains oncolytic potency [44]. Furthermore, pathway-reinforcing oncolytic VV have been generated that coordinately promote the IFN-beta pathway while deleting the B18R gene product, known to neutralize secreted type-I IFNs [106]. Zhang et al. have also generated an oncolytic VV from the Lister strain with triple insertional mutations in the F14.5 L, J2R (for $t k$ ), and A56R (encoding hemagglutinin) genetic loci of the viral genome [107]. VV produces a special form of virus particles called EEV, which can evade the neutralizing antibodies and complement-mediated disruption of the virus $[36,108]$. The EEV-enhanced strains of VVs displayed enhanced spread within tumors after systemic delivery, resulting in significantly improved antitumor effects, in addition to reduced clearance by neutralizing antibodies commonly developed in experimental models [30, 109].

Recently, new oncolytic VVs have been designed and studied in tumor models. Evans and colleagues have explored another viral gene targeting the nucleotide biosynthesis pathway and developed a new oncolytic VV in which the F4L viral gene encoding ribonucleotide reductase is deleted. This virus is a selective OV and is capable of promoting therapeutic anti-tumor immunity in association with a superior safety index in cancer models 
Table 4 Selective examples of oncolytic vaccinia virus (W) used in preclinical studies

\begin{tabular}{|c|c|c|c|c|c|c|}
\hline $\begin{array}{l}\text { Virus } \\
\text { name }\end{array}$ & Strain & Transgene & Mode of cell death & Antitumor activities, especially immunity & Tumor models & References \\
\hline $\begin{array}{l}\text { Pexa-Vec } \\
\text { (JX-594) }\end{array}$ & $\begin{array}{l}\text { Wyeth } \\
(t k-)\end{array}$ & GM-CSF & $\begin{array}{l}\text { Apoptosis and } \\
\text { necrosis } \\
\text { (ICD) }\end{array}$ & $\begin{array}{l}\text { Tumor cell infection and lysis; } \\
\text { antitumor immune response; tumor } \\
\text { vascular disruption }\end{array}$ & $\begin{array}{l}\text { hepatocellular } \\
\text { carcinoma (HCC) } \\
\text { and other cancers }\end{array}$ & $\begin{array}{l}{[63,104,} \\
125]\end{array}$ \\
\hline $\begin{array}{l}\text { VVDD- } \\
\text { GFP }\end{array}$ & $\begin{array}{l}\text { WR } \\
(t k-/ v g f-)\end{array}$ & $\begin{array}{l}\text { EGFP; } \\
\text { (later CD; GM-CSF) }\end{array}$ & $\begin{array}{l}\text { Necrosis and } \\
\text { apoptosis; } \\
\text { (ICD)) }\end{array}$ & $\begin{array}{l}\text { CD11b + cells and CD11b + Ly6G+ } \\
\text { cells (dendritic cells and neutrophils) }\end{array}$ & $\begin{array}{l}\text { Breast, colon, and } \\
\text { ovarian cancer } \\
\text { models }\end{array}$ & {$[105,120]$} \\
\hline $\begin{array}{l}\text { GLV-1 } \\
\text { h68 }\end{array}$ & $\begin{array}{l}\text { Lister } \\
\text { (deletion of } t k \\
\text { F14.5 L, A65R) }\end{array}$ & $\begin{array}{l}\text { Renilla luciferase- } \\
\text { GFP fusion protein, } \\
\beta \text {-galactosidase, } \\
\beta \text {-glucuronidase }\end{array}$ & $\begin{array}{l}\text { Apoptosis and } \\
\text { others }\end{array}$ & $\begin{array}{l}\text { Immune defense activation via IFN- } \\
\text { stimulated genes (STAT-1 and IRF-7), } \\
\text { cytokines, chemokines, and innate } \\
\text { immune effector function }\end{array}$ & $\begin{array}{l}\text { Breast cancer and } \\
\text { other cancer types }\end{array}$ & {$[107,198]$} \\
\hline $\begin{array}{l}\text { VG9- } \\
\text { GMCSF }\end{array}$ & $\begin{array}{l}\text { Tiantan Guang9 } \\
\text { strain (tk-) }\end{array}$ & GM-CSF & Unknown & $\begin{array}{l}\text { Antitumor activity and induced tumor- } \\
\text { specific immune response }\end{array}$ & Melanoma & [127] \\
\hline$\triangle F 4 L \triangle / 2 R$ & $\begin{array}{l}\text { WR } \\
(F 4 L-\text { and } t k-)\end{array}$ & Luciferase & Unknown & $\begin{array}{l}\text { Durable tumor-antigen specific cytotoxic } \\
\text { T-cell response }\end{array}$ & Bladder cancer & [110] \\
\hline CW & $\begin{array}{l}\text { Wyeth strain } \\
t k \text { - and repeated } \\
\text { selection }\end{array}$ & GFP & Unknown & $\begin{array}{l}\text { Complete regression of liver tumorigenicity } \\
\text { and metastasis to the colon. }\end{array}$ & $\mathrm{HCC}$ & [115] \\
\hline deW5 & $\begin{array}{l}\text { Chimeric W from } \\
\text { WY, MVA, WR, } \\
\text { and COP }\end{array}$ & $\begin{array}{l}\text { tk deletion and } \\
\text { fcu1 addition results } \\
\text { in deW5-fcu1 }\end{array}$ & Unknown & $\begin{array}{l}\text { Higher tumor selectivity and more viral } \\
\text { replication in cancer cells }\end{array}$ & Not tested yet & [113] \\
\hline $\begin{array}{l}\text { CF33 and } \\
\text { CF189 }\end{array}$ & $\begin{array}{l}\text { Chimeric } \\
\text { parapoxvirus }\end{array}$ & & Unknown & $\begin{array}{l}\text { Effective at low viral dose; abscopal } \\
\text { antitumor effect }\end{array}$ & $\begin{array}{l}\text { Triple negative } \\
\text { breast cancer and } \\
\text { colorectal cancer }\end{array}$ & {$[114,123]$} \\
\hline
\end{tabular}

[110]. It is interesting to note that both F4L and J2R $(t k)$ encode enzymes for nucleotide synthesis. In another study, Esteban and others showed that the WRDelta4 virus, with a combined deletion of four viral genes that act on metabolic, proliferation, and signaling pathways (A48R, B18R, C11R, and J2R), still effectively mediates anti-tumor benefit while retaining tumor selectivity in vivo. When applied in B16F10 melanoma models, strong viral attenuation, reduced virus dissemination, and efficient inhibition of tumor growth were observed, with a concurrent enhancement in neutrophil infiltration and the induction of tumor antigen-specific immunity [111].

Another strategy is quite unique. VV encodes two de-capping enzymes (D9 and D10) that remove protective caps from mRNA 5 '-termini, thus accelerating mRNA decay and limiting activation of host defenses. Mohr and associates showed that D9- or D10-deficient VACV are markedly attenuated in mice, but these VVs are effective when used as oncolytic viruses [112].

Another interesting strategy is to generate novel chimeric poxviruses via homologous recombination of different strains of $\mathrm{VV}$ or poxviruses or by natural selection in cancer cells themselves. Erbs and associates mixed four strains of VVs and generated deVV5, a novel chimeric poxvirus with improved oncolytic potency in human cancer cells [113]. Chen and colleagues generated another virus, CF189, by mixing different species of poxviruses; yielding a chimeric OV that is therapeutically effective in triple negative breast cancer models, even at low viral doses [114]. In other studies, Yoo et al. selected an OV designated CVV by repeated selective replication in cancerous tissues, with subsequent deletion of the viral $t k$ gene, yielding a therapeutic vector under investigation against metastatic liver cancer [115].

\section{Oncolytic VV induces immunogenic cell death}

A few years ago, we directly contributed to the conceptual evolution of immunogenic cell death (ICD). ICD was originally proposed by Zitvogel, Kroemer, and others, as a version of immunogenic apoptosis [116]. In 2013, we independently expanded the novel concept from the originally proposed immunogenic apoptosis to include other types of cell death, such as autophagic cell death, necroptosis, and pyroptosis $[6,117]$. This expanded concept of ICD has since been widely accepted by the scientific community [46, 118].

Accumulating evidence suggests that oncolytic VVs induce ICD in infected cancer cells and associated stromal cells. VV-induced lytic cell death elicits the release of immunogenic heat shock protein GRP94/gp96 [119]. We showed that the wild-type WR strain and geneticallyengineered vSP induced both necrosis and apoptosis, resulting in the release of high mobility group box 1 (HMGB1) from infected and dying cancer cells [44]. Another study showed that vvDD induced necrosis and infected cell release of ATP and HMGB1, two key danger 
molecules for initiation of the anti-tumor immune responses [120]. Another WR strain-derived OV also exhibited the ability to induce ICD in infected cancer cells [121]. Lister strain $t k$-deleted VV and a chimeric orthopoxvirus induced necroptosis (ICD) in ovarian and colorectal cancer cells [122, 123]. Interestingly, DCs infected by VV also die via ICD, which enhances $\mathrm{CD}^{+} \mathrm{T}$ cell proliferation [124]. In summary, oncolytic VVs induce ICD, providing the antigenic fuel for enhanced crosspriming of therapeutic $\mathrm{CD}^{+} \mathrm{T}$ cell responses. There remains significant room for improvement in such approaches based on the integration of combination strategies (Fig. 2).

\section{$V V$ armed with immuno-stimulatory genes for enhanced antitumor immunity}

Investigators have engineered oncolytic VVs with a variety of immunostimulatory genes. For example, VV strains of Wyeth, WR, and Tiantan have been armed with GM-CSF [63, 125-127], a cytokine known to sustain and support the function of DC. As we mentioned earlier, many of the previously created VVs expressing various cytokines used for cancer vaccines in the 1990s turned out to be tumorselective OVs. Recently, the Wang group has generated a novel vector expressing IL-10 and have demonstrated it to function as an effective therapeutic agent in a murine pancreatic cancer model [128]. Oncolytic VV expressing IL24 suppresses the growth of lung cancer [129]. We have shown that oncolytic VVs expressing CXCL11 or superagonist IL-15 are also potent inducers of antitumor immunity [130, 131]. Recently, we have modified a VV expressing an membrane-anchored IL-2 to modulate the TME and have effectively treated a variety of murine tumors without evidence of adverse events [132].

Using an alternate novel strategy, Song and colleagues armed an oncolytic VV with a gene encoding a secretory bispecific T-cell engager consisting of two single-chain variable fragments specific for CD3 and the tumor cell surface antigen EphA2 (EphA2-T-cell engager-armed VV (EphA2TEA-VV)). Administration of EphA2-TEA-VV and adoptive $\mathrm{T}$ cell transfer mediated superior anti-tumor benefit when compared to control VV plus T cells in a lung cancer xenograft model. This could represent a promising approach to improve oncolytic immunotherapy [133].

\section{Targeting the immunological TME}

Advanced cancers display a highly immunosuppressive TME [134]. In order for therapeutic regimens (especially immunotherapies) to work effectively, the TME requires re-conditioning to yield an immunologically favorable theater of operation [135]. The main goals for conditioning regimens are, i.) to enhance the immunogenicity of the tumor tissue in support of improved immune cell recognition and the cross-priming of a diversified therapeutic $\mathrm{T}$ cell repertoire and ii.) to recruit and maintain poly-functional anti-tumor innate and adaptive immune effector cells. It is worth pointing out that the virus itself is highly immunogenic and capable of promoting local inflammation. Indeed, recent studies support an operational paradigm in which effective oncolytic therapy and other forms of immunotherapy convert "cold" tumors into "hot" tumors $[98,136,137]$.

Such inflammatory conditioning however can lead to compensatory upregulation of regulatory pathways. For instance, local production of pro-inflammatory cytokines can stimulate upregulation in PGE2 production. In a recent study, the authors identified prostaglandin E2 (PGE2) in the tumor as a key mediator of resistance to immunotherapies. PGE2 is coupled with a suppressive chemokine profile and the presence of high numbers of granulocytic myeloid-derived suppressor cells (MDSC) in the TME. Oncolytic VV expressing the prostaglandin-inactivating enzyme hydroxyprostaglandin dehydrogenase 15 or addition of the COX-2 inhibitor celecoxib mitigates local immunosuppression, leading to profound changes in the immune status of the TME. As such, these regimens could sponsor robust adaptive anti-tumor immunity within the TME, and sensitize tumors to interventional immunotherapies [138].

\section{1). Combination with pharmaceutical drugs}

Pharmaceutical drugs may be used to modulate the innate and/or adaptive immune environment in the TME for improved virotherapy. Studies have shown that combined OV with histone deacetylase inhibitors (HDIs) improved viral replication and therapeutic efficacy [139]. Two studies showed that HDIs could enhance viral replication and the spread of an oncolytic VV inside the tumor by dampening cellular IFN responses and augmenting virus-induced apoptosis [140, 141]. We explored this combination using a drug cocktail consisting of IFN- $\alpha$, poly I:C, and a COX-2 inhibitor [142], which was previously shown to modulate the TME and expression of chemokines in vitro [143]. We showed that sequential treatment with an oncolytic VV and then the cocktail resulted in the upregulation of Th1-attracting chemokines and a reduction in levels of Treg-attracting chemokines (CCL22 and CXCL12), in association with enhanced trafficking of NK cells and tumor-specific $\mathrm{CD} 8^{+} \mathrm{T}$ cells into the TME. This combination led to pronounced anti-tumor activity and the extended long-term survival of mice bearing MC38 colon carcinomas. In another study, the authors combined the OV mpJX-594 with sunitinib (an oral, small-molecule, multi-targeted receptor tyrosine kinase inhibitor). This combined regimen worked through multiple mechanisms, with the virus targeting tumor blood vessels, spreading secondarily to tumor cells, and exerting tumor cell-killing 


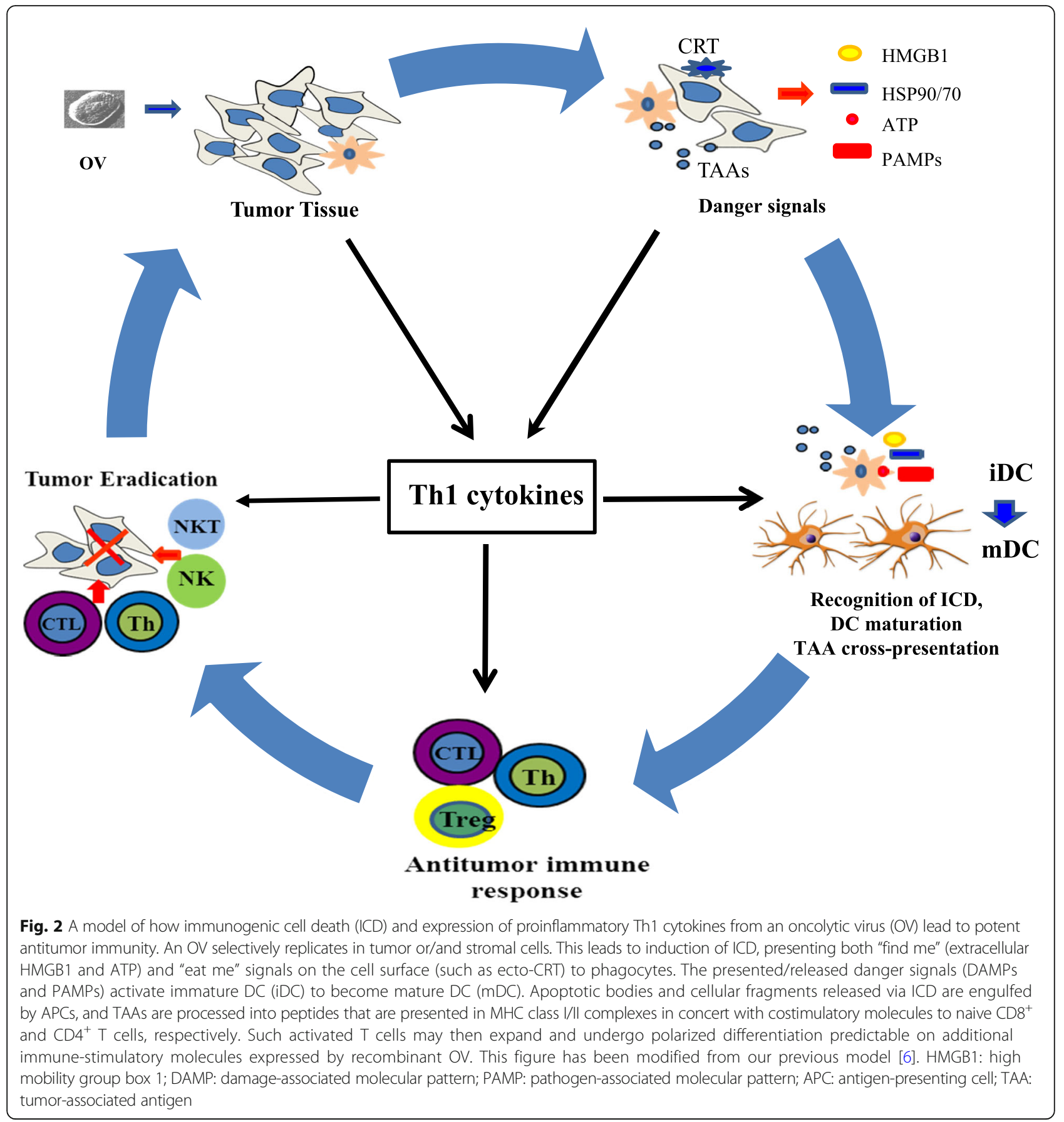

mediation by $\mathrm{CD} 8^{+} \mathrm{T}$ cells, which were amplified by the immunomodulatory action of sunitinib [144]. These studies illustrate that concerted innate and adaptive antitumor immunity can be modulated via pharmaceutical agents and OVs in the TME to achieve improved therapeutic benefits.

2). Combination of OVs with immune checkpoint blockade
We have explored the efficacy of a combined regimens using oncolytic $\mathrm{VV}$ and anti-PD-L1 antibody in murine tumor models [98]. Our key hypothesis was that an OV would not only elicit an anti-tumor adaptive immune response, but also virus-induced inflammation leading to upregulation of PD-L1 expression by both tumor and stromal cells, making the environment conditionally-responsive to anti-PD-L1-based antagonism. Indeed, we observed virus-induced expression of PD-L1 in the 
tumor tissue, with the combination treatment regimen yielding superior anti-tumor efficacy and extended overall survival [98]. Furthermore, a new oncolytic VV-expressing superagonist IL-15 elicits potent antitumor immunity, and when combined with anti-PD-1 Ab as a therapy, treated animals displayed dramatic tumor regression in a murine colon carcinoma model [131]. Additionally, Fend et al. showed that intratumoral injection of an oncolytic VV significantly altered TME infiltration by lymphocytes and inflammatory myeloid cells, with notably more $\mathrm{CD} 8^{+} \mathrm{TIL}$ and fewer Treg cells post-treatment. When combined with an ICD inducer (oxaliplatin), anti-PD1, or anti-CTLA4, the anti-tumor efficacy of OV was enhanced in an MCA205 sarcoma model [121]. It is therefore fully expected that combinations of oncolytic VV and immune checkpoint blockade will soon be investigated in a clinical setting.

\section{The EEV form of VV for immune evasion}

One unique property of poxviruses is the existence of two infectious forms as described earlier: the IMV and EEV forms [32, 145]. IMV is known to infect cells less efficiently than EEV, which is surrounded by an additional, trans-Golgi network-derived membrane. When the IMV binds HeLa cells, it activates a signaling cascade that is regulated by multiple factors, including the GTPases rac1 and rhoA, ezrin, and phosphorylation of both tyrosine and protein kinase $C$ [146]. Thus, the EEV membrane seems to have developed the capacity to silently enter cells. In 1996, Ichihashi observed that the EEV form of the virus escapes inactivation by neutralizing antibodies [147], and EEV has also been shown to resist complement due to the incorporation of host complement control proteins into its envelope [148]. The CEV/EEV outer membrane contains at least six viral proteins: A33, A34, A56, B5, F13, and K2 (for review, see Breiman and Smith, 2010) [149]. The glycoprotein A34R is required for infectivity of EEV [150]. Kirn et al. compared the oncolytic potential of low versus high EEV-producing strains of $\mathrm{VV}$ and showed that EEV-enhanced VV strains displayed improved spread within tumors after systemic delivery, resulting in significantly improved antitumor effects [109]. Our group has rationally designed A34R mutant (lysine- $151 \rightarrow$ glu) VV, resulting in greater production of EEV and improved therapeutic efficacy when applied in a peritoneal carcinomatosis model [30]. In the clinical setting, if an oncolytic VV is planned for repeated administration in the same patient, it will likely be preferred to deliver one that produces more of the EEV form after injection.

Different routes of delivery for oncolytic VVs OVs are conventionally delivered to tumors via three routes: local (intratumoral), systemic (intravenous, i.v.), and locoregional (such as intraperitoneal [i.p.] delivery to tumor).
Currently, the majority of preclinical studies have employed local OV injection. However, systemic delivery represents a major goal in the field of oncolytic virotherapy, as it would provide greater potential to effectively treat (potentially inaccessible) disseminated disease [151, 152]. Systemic delivery results in lower efficiency, a key reason for which is the rapid clearance of the viruses from the circulation before they reach their target sites. Tanabe and associates directly compared i.v. versus i.p. delivery of HSV-1 in a peritoneal tumor model in mice [153]. They concluded that i.p. administration of an oncolytic HSV-1 was associated with a far more restricted biodistribution, less toxicity, and greater efficacy against peritoneal metastases. Clinically, T-VEC has been only been approved to treat advanced melanoma via intralesional injection [154].

Theoretically, VV is ideally suited for systemic delivery, as it is partially resistant to complement and antibodymediated neutralization in the blood. Due to its relatively large size, it is preferentially deposited in tumors where the abnormal neovasculature exhibits enhanced permeability allowing for enhanced viral entry into the TME. It can spread to distant tissues, which is crucial for its ability to treat systemic disease. Clinically, after i.v. administration of an oncolytic $\mathrm{VV}$ and dose-related delivery, viral replication, and transgene expression has been observed in metastatic tumor sites in humans [155]. In fact, the three oncolytic VVs in the clinical studies, namely Pex-Vec (Wyeth strain) [155, 156], vvDD (WR strain) [157], and GL-ONC1 (Lister strain) [158], have all been delivered intravenously to patients. As for which route is clinically superior, no randomized comparisons using oncolytic VV have yet been performed. In the absence of such information, we hypothesize that conclusions drawn from studies with other OVs will be applicable to oncolytic VVs.

Anti-vascular effects exerted by oncolytic VV PexaVec mediates the unexpected effect of disrupting the tumor-associated vasculature in both mice and humans $[144,159,160]$. Further studies have shown that PexaVec can infect and replicate in tumor-associated vascular endothelial cells, with efficient replication and transgene expression in normal endothelial cells dependent on either VEGF or FGF-2 stimulation [160]. Bell and associates recently showed that this expanded tropism to tumor-associated endothelial cells is a consequence of VEGF-mediated suppression of the intrinsic anti-viral response. One key component in this anti-vascular mechanism of action is the induction of PRD1-BF1/ Blimp1 expression [161]. In mice, this disruption led to massive tumor necrosis. In humans, intraveneous PexaVec was used to treat advanced HCC, a hypervascular and VEGF-rich tumor type. Pexa-Vec treatment led to 
the disruption of tumor perfusion in as few as 5 days in both patients treated with this regimen. Based on this limited information, it seems that virus-induced antivascular activity may significantly contribute to therapeutic efficacy of this oncolytic VV. However, this supposition warrants verification as the massive necrosis induced by tumor-specific vascular collapse triggered by the VV may be highly-immunosuppressive, thus dampening the magnitude and/or durability of any resultant anti-tumor immunity.

\section{Clinical studies of VV as oncolytic virus}

The development of Pexa-Vec showcases the advancement of oncolytic VVs from preclinical studies to clinical trialing. This virus was initially developed as a viral vector to express GM-CSF as a cancer vaccine and was then applied in patients with cutaneous melanoma in the late 1990s [63]. Only recently has this virus been rediscovered as an oncolytic virus and renamed JX-594, and later PexaVec (by SilliJen Biotherapeutics) [125]. It has undergone testing in multiple phase I/II clinical trials in patients with HCC $[155,159,162]$, where viral replication, GM-CSF secretion from infected cancer cells, and the induction of anti-tumor immune responses have been demonstrated. More importantly, the authors demonstrated that extended patient survival was significantly related to the dosage of the virus administered, with a median survival of 14.1 months compared to 6.7 months in the high- vs. low-dose treatment cohorts, respectively [162]. In a related study, Pexa-Vec has been shown to induce antibodymediated, complement-dependent cancer cell lysis in cancer patients [163]. Currently, Pexa-Vec along with the TKI sorafenib are undergoing testing in a phase III PHOCUS global clinical study for patients with HCC.

Other strains of oncolytic VVs have been tested in early phase clinical trials. Lister strain-derived GL-ONC1 is safe in patients with locoregionally-advanced head/neck cancer undergoing standard chemoradiotherapy [158] or in patients with peritoneal carcinomatosis [164], and warrants further clinical studies. We have been studying the WR strain-derived OVs and have completed two phase I clinical trials of vvDD-CDSR in patients with advanced-stage solid cancers $[157,165]$. In all of these clinical trials, no severe adverse effects have been reported. To date, we have observed some clinical responses, but only amongst melanoma patients, which may be related to its consensus as one of the most immunogenic forms of cancer [166, 167].

How do different types of cancer and different immune environments in the tumor, surrounding normal tissues, or organs impact OVs, especially oncolytic VVmediated and immunotherapeutic OVs? These remain complicated issues that will need to be systematically evaluated for further optimization of OV-based therapeutic approaches. Based on numerous studies, a growing consensus is that there is a highly-positive correlation between cancer immunogenicity and efficacy of immunotherapy, including oncolytic immunotherapy. Melanoma is considered the most immunogenic type of cancer, and thus the most susceptible cancer to immunotherapy. For this reason, many clinical trials on cancer immunotherapy have been performed on melanoma, and the first oncolytic virus approved by the FDA is for patients with advanced melanoma. Some other types of cancers also display comparatively high immunogenicity, e.g., lung squamous cell carcinoma, bladder cancer, and colorectal cancer with MSI-H. These disease indications may also represent preferred targets for interventional oncolytic immunotherapy. The immune environment's yin and yang roles in OV-mediated therapy is also an important consideration. On one hand, an immunosuppressive environment supports better viral replication, but this also dampens the induction of potent antitumor immunity. On the other hand, a more immunogenic environment promotes the premature clearance of $\mathrm{OV}$, thus limiting its potential to activate and sustain therapeutic anti-tumor immunity.

\section{Conclusion and perspectives}

Numerous studies have now shown that VVs and other poxviruses have limited therapeutic efficacy as cancer vaccines when used alone. In fact, this limited efficacy has been a general concern for the whole field of cancer vaccines in the past. Sub-optimal vaccine design and an immunosuppressive TME are the root causes for the inability of the immune system to mediate cancer eradication $[168,169]$. As such, key areas for improvements in viral vector design must include the consideration of strategies to reverse the immunosuppressive TME. Therefore, one exciting area of research will be further improvements of poxvirus vectors. Table 1 lists over 20 candidate genes for genetic engineering to improve viral vector immunogenicity. However, it is important to note that even though increased immunogenicity of the virus will be advantageous to its use as a cancer vaccine, this represents a major disadvantage to an oncolytic virus, as the increased immune response to the virus will lead to premature clearance of the vector, thus reducing oncolytic potency. Thus, strategies need to be carefully planned when it comes to developing new recombinant poxvirus as a pure cancer vaccine vector or as an $\mathrm{OV}$, which represents a special type of cancer vaccine.

It is worth pointing out again that VVs and other OVs could serve as excellent platforms for multimodal cancer therapeutics $[8,170]$. They can be armed not only with genes for immune-stimulating, anti-angiogenic, and prodrug therapy, but also with reporter genes for imaging and serial therapeutic monitoring. VVs have been investigated 
in combination with chemo-, radio-, and other immunotherapeutic modalities. Some of these rational combinations have led to exciting therapeutic results in preclinical studies and warrant further clinical testing in human patients. Pexa-Vec combined with sorafenib in a global phase III trial for HCC showcases such a promising development.

A number of hurdles remain that limit the widespread use of oncolytic VV, just as is the case for other OVs $[171,172]$. The first impediment is the limited efficiency of delivering $\mathrm{OV}$ to and propagating it throughout the entire tumor lesion, as well as, the ability to infect disseminated cancer cells over distance. In this regard, the EEV form of the virus may provide a tool to overcome such a hurdle, by evading clearance and permitting infect of distant tumor sites. A second hurdle involves the need to develop systemic antitumor immunity to impact disseminated disease, which typically evolves over time [173]. Third, recent evidence suggests that microbiota play an important role not only in the initiation, progression, and dissemination of a variety of cancers, but also in patient responsiveness to interventional immunotherapies, including immunogenic tumor cell death-inducing chemotherapies and immune checkpoint blockade. Currently, we have little knowledge for the potential role of microbiota in host responsiveness to $\mathrm{VV}$ or other OV-mediated cancer therapy. Finally, over 200 genes are encoded by the viral genome of $\mathrm{VV}$, yet the functions of half of these genes remains unknown. Therefore, further understanding of the biology of the virus and viral gene functions is expected to improve our ability to manipulate these viruses to optimize their safety and efficacy when applied as cancer vaccines and/ or oncolytic immunotherapies. In summary, despite these technical speed-bumps, the future of VV for use in cancer vaccines and oncolytic immunotherapies appears bright, especially when integrated in the setting of rational combination approaches that favor protective over regulatory immunity.

\section{Acknowledgements}

We thank Christine Burr for critically reviewing and editing the manuscript.

\section{Funding}

This work was supported by internal funds from the University of Pittsburgh and by National Institutes of Health grants 1R01 CA155925, R21CA205727-01, and 1R01CA168912.

\section{Availability of data and materials}

Not applicable.

\section{Authors' contributions}

ZSG collected and read relevant papers and designed and drafted the manuscript. WJS polished the whole manuscript. All other authors made suggestions for the manuscript. All authors read and approved the final manuscript.

Ethics approval and consent to participate Not applicable.
Consent for publication

Not applicable.

\section{Competing interests}

ZSG and DLB serve as scientific advisors to ICell Kealex Therapeutics. DLB has financial interest with SillaJen Biotherapeutics. Pexa-Vec, a product discussed in this review, is manufactured by SillaJen. All other authors declare no conflict of interest.

\section{Publisher's Note}

Springer Nature remains neutral with regard to jurisdictional claims in published maps and institutional affiliations.

\section{Author details}

${ }^{1}$ UPMC Hillman Cancer Center, Pittsburgh, PA, USA. ²Department of Surgery, University of Pittsburgh School of Medicine, Pittsburgh, PA, USA.

${ }^{3}$ Department of Immunology, University of Pittsburgh School of Medicine, Pittsburgh, PA, USA. ${ }^{4}$ Fujian Tianjian Pharmaceutical Co. Ltd., Sanming, Fujian, China. ${ }^{5}$ Department of Dermatology, University of Pittsburgh School of Medicine, Pittsburgh, PA, USA. ${ }^{6}$ Georgia Cancer Center, Medical College of Georgia, Augusta University, Augusta, GA, USA

Received: 6 August 2018 Accepted: 26 December 2018

Published online: 09 January 2019

\section{References}

1. Schlom J. Therapeutic cancer vaccines: current status and moving forward. J Natl Cancer Inst. 2012;104:599-613.

2. Farkona S, Diamandis EP, Blasutig IM. Cancer immunotherapy: the beginning of the end of cancer? BMC Med. 2016;14:73.

3. Wei SC, Duffy CR, Allison JP. Fundamental mechanisms of immune checkpoint blockade therapy. Cancer Discov. 2018;8:1069-86.

4. Guo ZS. The 2018 Nobel prize in medicine goes to cancer immunotherapy (editorial for BMC cancer). BMC Cancer. 2018;18:1086.

5. Toda M, Rabkin SD, Kojima H, Martuza RL. Herpes simplex virus as an in situ cancer vaccine for the induction of specific anti-tumor immunity. Hum Gene Ther. 1999;10:385-93.

6. Bartlett DL, Liu Z, Sathaiah M, Ravindranathan R, Guo Z, He Y, Guo ZS. Oncolytic viruses as therapeutic cancer vaccines. Mol Cancer. 2013;12:103.

7. Russell SJ, Barber GN. Oncolytic viruses as antigen-agnostic cancer vaccines. Cancer Cell. 2018;33:599-605

8. Guo ZS, Bartlett DL. Oncolytic viruses as platform for multimodal cancer therapeutics: a promising land. Cancer Gene Ther. 2014;21:261-3.

9. Bommareddy PK, Shettigar M, Kaufman HL. Integrating oncolytic viruses in combination cancer immunotherapy. Nat Rev Immunol. 2018;18:498-513.

10. Moss B. Poxviridae. In: Knipe DM, Howley PM, editors. Fields virology. 6th ed. Philadelphia: Wolters Kluwer Health/Lippincott Williams \& Wilkins; 2013. p. 2129-59.

11. Carter GC, Law M, Hollinshead M, Smith GL. Entry of the vaccinia virus intracellular mature virion and its interactions with glycosaminoglycans. J Gen Virol. 2005;86:1279-90.

12. Broyles SS. Vaccinia virus transcription. J Gen Virol. 2003;84:2293-303.

13. Tolonen N, Doglio L, Schleich S, Krijnse LJ. Vaccinia virus DNA replication occurs in endoplasmic reticulum-enclosed cytoplasmic mini-nuclei. Mol Biol Cell. 2001:12:2031-46.

14. Senkevich TG, Ojeda S, Townsley A, Nelson GE, Moss B. Poxvirus multiprotein entry-fusion complex. Proc Natl Acad Sci U S A. 2005;102: 18572-7.

15. Postigo A, Ramsden AE, Howell M, Way M. Cytoplasmic ATR activation promotes vaccinia virus genome replication. Cell Rep. 2017;19:1022-32.

16. Katsafanas GC, Moss B. Colocalization of transcription and translation within cytoplasmic poxvirus factories coordinates viral expression and subjugates host functions. Cell Host Microbe. 2007;2:221-8.

17. Salzman NP. The rate of formation of vaccinia deoxyribonucleic acid and vaccinia virus. Virology. 1960;10:150-2.

18. Roberts $\mathrm{KL}$, Smith GL. Vaccinia virus morphogenesis and dissemination. Trends Microbiol. 2008;16:472-9.

19. Chung CS, Hsiao JC, Chang YS, Chang W. A27L protein mediates vaccinia virus interaction with cell surface heparan sulfate. J Virol. 1998;72:1577-85.

20. Ho Y, Hsiao JC, Yang MH, Chung CS, Peng YC, Lin TH, Chang W, Tzou DL. The oligomeric structure of vaccinia viral envelope protein $A 27 \mathrm{~L}$ is essential 
for binding to heparin and heparan sulfates on cell surfaces: a structural and functional approach using site-specific mutagenesis. J Mol Biol. 2005; 349:1060-71.

21. Law M, Smith GL. Antibody neutralization of the extracellular enveloped form of vaccinia virus. Virology. 2001;280:132-42.

22. Maruri-Avidal L, Weisberg AS, Bisht H, Moss B. Analysis of viral membranes formed in cells infected by a vaccinia virus L2-deletion mutant suggests their origin from the endoplasmic reticulum. J Virol. 2013;87:1861-71.

23. Herrero-Martinez E, Roberts KL, Hollinshead M, Smith GL. Vaccinia virus intracellular enveloped virions move to the cell periphery on microtubules in the absence of the A36R protein. J Gen Virol. 2005;86:2961-8.

24. Newsome TP, Scaplehorn N, Way M. SRC mediates a switch from microtubule- to actin-based motility of vaccinia virus. Science. 2004;306: 124-9.

25. Reeves PM, Bommarius B, Lebeis S, McNulty S, Christensen J, Swimm A, Chahroudi A, Chavan R, Feinberg MB, Veach D, et al. Disabling poxvirus pathogenesis by inhibition of Abl-family tyrosine kinases. Nat Med. 2005;11: 731-9.

26. Newsome TP, Weisswange I, Frischknecht F, Way M. Abl collaborates with Src family kinases to stimulate actin-based motility of vaccinia virus. Cell Microbiol. 2006;8:233-41.

27. Moss B. Poxvirus entry and membrane fusion. Virology. 2006;344:48-54.

28. Payne $L G$. Identification of the vaccinia hemagglutinin polypeptide from a cell system yielding large amounts of extracellular enveloped virus. J Virol. 1979:31:147-55

29. Blasco R, Sisler JR, Moss B. Dissociation of progeny vaccinia virus from the cell membrane is regulated by a viral envelope glycoprotein: effect of a point mutation in the lectin homology domain of the A34R gene. J Virol. 1993;67:3319-25.

30. Thirunavukarasu P, Sathaiah M, Gorry MC, O'Malley ME, Ravindranathan R, Austin F, Thorne SH, Guo ZS, Bartlett DL. A rationally designed A34R mutant oncolytic poxvirus: improved efficacy in peritoneal carcinomatosis. Mol Ther 2013;21:1024-33.

31. Handa Y, Durkin CH, Dodding MP, Way M. Vaccinia virus F11 promotes viral spread by acting as a PDZ-containing scaffolding protein to bind myosin9A and inhibit RhoA signaling. Cell Host Microbe. 2013;14:51-62.

32. Smith GL, Vanderplasschen A. Extracellular enveloped vaccinia virus. Entry, egress, and evasion. Adv Exp Med Biol. 1998;440:395-414.

33. Doceul V, Hollinshead M, van der Linden L, Smith GL. Repulsion of superinfecting virions: a mechanism for rapid virus spread. Science. 2010; 327:873-6.

34. Doceul V, Hollinshead M, Breiman A, Laval K, Smith GL. Protein B5 is required on extracellular enveloped vaccinia virus for repulsion of superinfecting virions. J Gen Virol. 2012;93:1876-86.

35. Morissette G, Flamand L. Herpesviruses and chromosomal integration. J Virol. 2010;84:12100-9.

36. Smith GL, Benfield CT, Maluquer de Motes C, Mazzon M, Ember SW, Ferguson BJ, Sumner RP. Vaccinia virus immune evasion: mechanisms, virulence and immunogenicity. J Gen Virol. 2013;94:2367-92.

37. Di Pilato M, Mejias-Perez E, Zonca M, Perdiguero B, Gomez CE, Trakala M, Nieto J, Najera JL, Sorzano CO, Combadiere C, et al. NFkappaB activation by modified vaccinia virus as a novel strategy to enhance neutrophil migration and HIV-specific T-cell responses. Proc Natl Acad Sci U S A. 2015;112:E1333-42.

38. Di Pilato M, Mejias-Perez E, Sorzano COS, Esteban M. Distinct roles of vaccinia virus NF-kappaB inhibitor proteins $A 52, B 15$, and $K 7$ in the immune response. J Virol. 2017;91:e00575-17.

39. Bravo Cruz AG, Han A, Roy EJ, Guzman AB, Miller RJ, Driskell EA, O'Brien WD $\mathrm{Jr}$, Shisler JL. Deletion of the K1L gene results in a vaccinia virus that is less pathogenic due to muted innate immune responses, yet still elicits protective immunity. J Virol. 2017;91:e00542-17.

40. Maluquer de Motes C, Smith GL. Vaccinia virus protein A49 activates Wnt signalling by targetting the E3 ligase beta-TrCP. J Gen Virol. 2017; 98:3086-92

41. Holgado MP, Falivene J, Maeto C, Amigo M, Pascutti MF, Vecchione MB, Bruttomesso A, Calamante G, Del Medico-Zajac MP, Gherardi MM. Deletion of A44L, A46R and C12L vaccinia virus genes from the MVA genome improved the vector immunogenicity by modifying the innate immune response generating enhanced and optimized specific T-cell responses. Viruses. 2016;8:139.
42. Veyer DL, Carrara G, Maluquer de Motes C, Smith GL. Vaccinia virus evasion of regulated cell death. Immunol Lett. 2017;186:68-80.

43. Nichols DB, De Martini W, Cottrell J. Poxviruses utilize multiple strategies to inhibit apoptosis. Viruses. 2017;9:215.

44. Guo ZS, Naik A, O'Malley ME, Popovic P, Demarco R, Hu Y, Yin X, Yang S, Zeh $\mathrm{HJ}$, Moss $\mathrm{B}$, et al. The enhanced tumor selectivity of an oncolytic vaccinia lacking the host range and antiapoptosis genes SPI-1 and SPI- 2 . Cancer Res. 2005;65:9991-8.

45. Legrand FA, Verardi PH, Chan KS, Peng Y, Jones LA, Yilma TD. Vaccinia viruses with a serpin gene deletion and expressing IFN-gamma induce potent immune responses without detectable replication in vivo. Proc Natl Acad Sci U S A. 2005;102:2940-5.

46. Galluzzi L, Buque A, Kepp O, Zitvogel L, Kroemer G. Immunogenic cell death in cancer and infectious disease. Nat Rev Immunol. 2017;17:97-111.

47. Koehler H, Cotsmire S, Langland J, Kibler KV, Kalman D, Upton JW, Mocarski ES, Jacobs BL. Inhibition of DAl-dependent necroptosis by the Z-DNA binding domain of the vaccinia virus innate immune evasion protein, E3. Proc Natl Acad Sci U S A. 2017;114:11506-11.

48. Schock SN, Chandra NV, Sun Y, Irie T, Kitagawa Y, Gotoh B, Coscoy L, Winoto A. Induction of necroptotic cell death by viral activation of the RIG-I or STING pathway. Cell Death Differ. 2017;24:615-25.

49. Dai P, Wang W, Cao H, Avogadri F, Dai L, Drexler I, Joyce JA, Li XD, Chen Z, Merghoub T, et al. Modified vaccinia virus Ankara triggers type I IFN production in murine conventional dendritic cells via a cGAS/STINGmediated cytosolic DNA-sensing pathway. PLoS Pathog. 2014;10:e1003989.

50. Dai P, Wang W, Yang N, Serna-Tamayo C, Ricca JM, Zamarin D, Shuman S, Merghoub T, Wolchok JD, Deng L. Intratumoral delivery of inactivated modified vaccinia virus Ankara (iMVA) induces systemic antitumor immunity via STING and Batf3-dependent dendritic cells. Sci Immunol. 2017;2:eaal1713.

51. Fu J, Kanne DB, Leong M, Glickman LH, McWhirter SM, Lemmens E, Mechette K, Leong JJ, Lauer P, Liu W, et al. STING agonist formulated cancer vaccines can cure established tumors resistant to PD-1 blockade. Sci Transl Med. 2015;7:283ra252.

52. Smith CL, Mirza F, Pasquetto V, Tscharke DC, Palmowski MJ, Dunbar PR, Sette A, Harris AL, Cerundolo V. Immunodominance of poxviral-specific CTL in a human trial of recombinant-modified vaccinia Ankara. J Immunol. 2005; 175:8431-7.

53. Raafat N, Sadowski-Cron C, Mengus C, Heberer M, Spagnoli GC, Zajac P. Preventing vaccinia virus class-I epitopes presentation by HSV-ICP47 enhances the immunogenicity of a TAP-independent cancer vaccine epitope. Int J Cancer. 2012;131:E659-69.

54. Hodge JW, McLaughlin JP, Abrams SI, Shupert WL, Schlom J, Kantor JA. Admixture of a recombinant vaccinia virus containing the gene for the costimulatory molecule B7 and a recombinant vaccinia virus containing a tumor-associated antigen gene results in enhanced specific T-cell responses and antitumor immunity. Cancer Res. 1995;55:3598-603.

55. Hodge JW, Sabzevari H, Yafal AG, Gritz L, Lorenz MG, Schlom J. A triad of costimulatory molecules synergize to amplify T-cell activation. Cancer Res. 1999:59:5800-7.

56. Tsang KY, Palena C, Yokokawa J, Arlen PM, Gulley JL, Mazzara GP, Gritz L, Yafal AG, Ogueta S, Greenhalgh P, et al. Analyses of recombinant vaccinia and fowlpox vaccine vectors expressing transgenes for two human tumor antigens and three human costimulatory molecules. Clin Cancer Res. 2005; 11:1597-607.

57. Ylosmaki E, Malorzo C, Capasso C, Honkasalo O, Fusciello M, Martins B, Ylosmaki L, Louna A, Feola S, Paavilainen $\mathrm{H}$, et al. Personalized cancer vaccine platform for clinically relevant oncolytic enveloped viruses. Mol Ther. 2018;26:2315-25

58. Kim HS, Kim-Schulze S, Kim DW, Kaufman HL. Host lymphodepletion enhances the therapeutic activity of an oncolytic vaccinia virus expressing 4-1BB ligand. Cancer Res. 2009;69:8516-25.

59. Schaedler E, Remy-Ziller C, Hortelano J, Kehrer N, Claudepierre MC, Gatard T, Jakobs C, Preville X, Carpentier AF, Rittner K. Sequential administration of a MVA-based MUC1 cancer vaccine and the TLR9 ligand Litenimod (Li28) improves local immune defense against tumors. Vaccine. 2017;35:577-85.

60. Remy-Ziller C, Thioudellet C, Hortelano J, Gantzer M, Nourtier V, Claudepierre MC, Sansas B, Preville X, Bendjama K, Quemeneur E, et al. Sequential administration of MVA-based vaccines and PD-1/PD-L1-blocking antibodies confers measurable benefits on tumor growth and survival: preclinical studies with MVA-betaGal and MVA-MUC1 (TG4010) in a murine tumor model. Hum Vaccin Immunother. 2017;14:140-5. 
61. Foy SP, Mandl SJ, dela Cruz T, Cote JJ, Gordon EJ, Trent E, Delcayre A, Breitmeyer J, Franzusoff A, Rountree RB. Poxvirus-based active immunotherapy synergizes with CTLA-4 blockade to increase survival in a murine tumor model by improving the magnitude and quality of cytotoxic T cells. Cancer Immunol Immunother. 2016;65:537-49.

62. Wallack MK, Sivanandham M, Balch CM, Urist MM, Bland KI, Murray D, Robinson WA, Flaherty LE, Richards JM, Bartolucci AA, et al. A phase III randomized, double-blind multiinstitutional trial of vaccinia melanoma oncolysate-active specific immunotherapy for patients with stage II melanoma. Cancer. 1995;75:34-42.

63. Mastrangelo MJ, Maguire HC Jr, Eisenlohr LC, Laughlin CE, Monken CE, McCue PA, Kovatich AJ, Lattime EC. Intratumoral recombinant GM-CSFencoding virus as gene therapy in patients with cutaneous melanoma. Cancer Gene Ther. 1999;6:409-22.

64. Zajac P, Oertli D, Marti W, Adamina M, Bolli M, Guller U, Noppen C, Padovan E, Schultz-Thater E, Heberer $M$, et al. Phase I/II clinical trial of a nonreplicative vaccinia virus expressing multiple HLA-A0201-restricted tumor-associated epitopes and costimulatory molecules in metastatic melanoma patients. Hum Gene Ther. 2003;14:1497-510.

65. Oertli D, Marti WR, Zajac P, Noppen C, Kocher T, Padovan E, Adamina M, Schumacher R, Harder F, Heberer M, et al. Rapid induction of specific cytotoxic $T$ lymphocytes against melanoma-associated antigens by a recombinant vaccinia virus vector expressing multiple immunodominant epitopes and costimulatory molecules in vivo. Hum Gene Ther. 2002;13: 569-75.

66. Kaufman HL, Deraffele G, Mitcham J, Moroziewicz D, Cohen SM, HurstWicker KS, Cheung K, Lee DS, Divito J, Voulo M, et al. Targeting the local tumor microenvironment with vaccinia virus expressing B7.1 for the treatment of melanoma. J Clin Invest. 2005;115:1903-12.

67. Kaufman HL, Cohen S, Cheung K, DeRaffele G, Mitcham J, Moroziewicz D, Schlom J, Hesdorffer C. Local delivery of vaccinia virus expressing multiple costimulatory molecules for the treatment of established tumors. Hum Gene Ther. 2006;17:239-44.

68. Mulryan K, Ryan MG, Myers KA, Shaw D, Wang W, Kingsman SM, Stern PL, Carroll MW. Attenuated recombinant vaccinia virus expressing oncofetal antigen (tumor-associated antigen) 5 T4 induces active therapy of established tumors. Mol Cancer Ther. 2002;1:1129-37.

69. Harrop R, Connolly N, Redchenko I, Valle J, Saunders M, Ryan MG, Myers KA, Drury N, Kingsman SM, Hawkins RE, et al. Vaccination of colorectal cancer patients with modified vaccinia Ankara delivering the tumor antigen 5T4 (TroVax) induces immune responses which correlate with disease control: a phase I/II trial. Clin Cancer Res. 2006;12:3416-24.

70. Harrop R, Drury N, Shingler W, Chikoti P, Redchenko I, Carroll MW, Kingsman SM, Naylor S, Melcher A, Nicholls J, et al. Vaccination of colorectal cancer patients with modified vaccinia Ankara encoding the tumor antigen 5T4 (TroVax) given alongside chemotherapy induces potent immune responses. Clin Cancer Res. 2007;13:4487-94.

71. Kaufman HL, Taback B, Sherman W, Kim DW, Shingler WH, Moroziewicz D, DeRaffele G, Mitcham J, Carroll MW, Harrop R, et al. Phase II trial of modified vaccinia Ankara (MVA) virus expressing 5T4 and high dose Interleukin-2 (IL-2) in patients with metastatic renal cell carcinoma. J Transl Med. 2009;7:2.

72. Amato RJ, Shingler W, Goonewardena M, de Belin J, Naylor S, Jac J, Willis J, Saxena S, Hernandez-McClain J, Harrop R. Vaccination of renal cell cancer patients with modified vaccinia Ankara delivering the tumor antigen 5T4 (TroVax) alone or administered in combination with interferon-alpha (IFNalpha): a phase 2 trial. J Immunother. 2009:32:765-72.

73. Amato RJ, Hawkins RE, Kaufman HL, Thompson JA, Tomczak P, Szczylik C, McDonald M, Eastty S, Shingler WH, de Belin J, et al. Vaccination of metastatic renal cancer patients with MVA-5T4: a randomized, double-blind, placebo-controlled phase III study. Clin Cancer Res. 2010;16:5539-47.

74. Eder JP, Kantoff PW, Roper K, Xu GX, Bubley GJ, Boyden J, Gritz L, Mazzara G, Oh WK, Arlen $P$, et al. A phase I trial of a recombinant vaccinia virus expressing prostate-specific antigen in advanced prostate cancer. Clin Cancer Res. 2000;6:1632-8.

75. Gulley J, Chen AP, Dahut W, Arlen PM, Bastian A, Steinberg SM, Tsang K, Panicali D, Poole D, Schlom J, et al. Phase I study of a vaccine using recombinant vaccinia virus expressing PSA (rV-PSA) in patients with metastatic androgen-independent prostate cancer. Prostate. 2002;53:109-17.

76. Kaufman HL, Wang W, Manola J, DiPaola RS, Ko YJ, Sweeney C, Whiteside TL, Schlom J, Wilding G, Weiner LM. Phase II randomized study of vaccine treatment of advanced prostate cancer (E7897): a trial of the eastern cooperative oncology group. J Clin Oncol. 2004;22:2122-32.

77. DiPaola RS, Plante M, Kaufman H, Petrylak DP, Israeli R, Lattime E, Manson K, Schuetz T. A phase I trial of pox PSA vaccines (PROSTVAC-VF) with B7-1, ICAM-1, and LFA-3 co-stimulatory molecules (TRICOM) in patients with prostate cancer. J Transl Med. 2006:4:1.

78. Kantoff PW, Schuetz TJ, Blumenstein BA, Glode LM, Bilhartz DL, Wyand M, Manson K, Panicali DL, Laus R, Schlom J, et al. Overall survival analysis of a phase II randomized controlled trial of a Poxviral-based PSA-targeted immunotherapy in metastatic castration-resistant prostate cancer. J Clin Oncol. 2010;28:1099-105.

79. Gulley JL, Arlen PM, Madan RA, Tsang KY, Pazdur MP, Skarupa L, Jones JL, Poole DJ, Higgins JP, Hodge JW, et al. Immunologic and prognostic factors associated with overall survival employing a poxviral-based PSA vaccine in metastatic castrate-resistant prostate cancer. Cancer Immunol Immunother. 2010;59:663-74.

80. Quoix E, Ramlau R, Westeel V, Papai Z, Madroszyk A, Riviere A, Koralewski P, Breton JL, Stoelben E, Braun D, et al. Therapeutic vaccination with TG4010 and first-line chemotherapy in advanced non-small-cell lung cancer: a controlled phase 2B trial. Lancet Oncol. 2011;12:1125-33.

81. Ramlau R, Quoix E, Rolski J, Pless M, Lena H, Levy E, Krzakowski M, Hess D, Tartour E, Chenard MP, et al. A phase II study of Tg4010 (Mva-Muc1-II2) in association with chemotherapy in patients with stage III/V non-small cell lung cancer. J Thorac Oncol. 2008;3:735-44.

82. Quoix E, Lena H, Losonczy G, Forget F, Chouaid C, Papai Z, Gervais R, Ottensmeier C, Szczesna A, Kazarnowicz A, et al. TG4010 immunotherapy and first-line chemotherapy for advanced non-small-cell lung cancer (TIME): results from the phase $2 \mathrm{~b}$ part of a randomised, double-blind, placebocontrolled, phase 2b/3 trial. Lancet Oncol. 2016;17:212-23.

83. Kaufman HL, Kim-Schulze S, Manson K, DeRaffele G, Mitcham J, Seo KS, Kim DW, Marshall J. Poxvirus-based vaccine therapy for patients with advanced pancreatic cancer. J Transl Med. 2007;5:60.

84. Gulley JL, Arlen PM, Tsang KY, Yokokawa J, Palena C, Poole DJ, Remondo C,

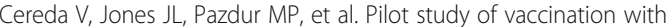
recombinant CEA-MUC-1-TRICOM poxviral-based vaccines in patients with metastatic carcinoma. Clin Cancer Res. 2008;14:3060-9.

85. Mohebtash M, Tsang KY, Madan RA, Huen NY, Poole DJ, Jochems C, Jones J, Ferrara T, Heery CR, Arlen PM, et al. A pilot study of MUC-1/CEA/TRICOM poxviral-based vaccine in patients with metastatic breast and ovarian cancer. Clin Cancer Res. 2011;17:7164-73.

86. Heery CR, Ibrahim NK, Arlen PM, Mohebtash M, Murray JL, Koenig K, Madan RA, McMahon S, Marte JL, Steinberg SM, et al. Docetaxel alone or in combination with a therapeutic cancer vaccine (PANVAC) in patients with metastatic breast cancer: a randomized clinical trial. JAMA Oncol. 2015;1: 1087-95.

87. Schumacher TN, Schreiber RD. Neoantigens in cancer immunotherapy. Science. 2015;348:69-74.

88. Balachandran VP, Luksza M, Zhao JN, Makarov V, Moral JA, Remark R, Herbst B, Askan G, Bhanot U, Senbabaoglu Y, et al. Identification of unique neoantigen qualities in long-term survivors of pancreatic cancer. Nature. 2017:551:512-6.

89. Ott PA, Hu Z, Keskin DB, Shukla SA, Sun J, Bozym DJ, Zhang W, Luoma A, Giobbie-Hurder $A$, Peter $L$, et al. An immunogenic personal neoantigen vaccine for patients with melanoma. Nature. 2017;547:217-21.

90. Sahin U, Derhovanessian E, Miller M, Kloke BP, Simon P, Lower M, Bukur V, Tadmor AD, Luxemburger U, Schrors B, et al. Personalized RNA mutanome vaccines mobilize poly-specific therapeutic immunity against cancer. Nature. 2017:547:222-6.

91. Laumont CM, Vincent K, Hesnard L, Audemard É, Bonneil É, Laverdure J-P, Gendron P, Courcelles M, Hardy M-P, Côté C, et al. Noncoding regions are the main source of targetable tumor-specific antigens. Sci Transl Med. 2018; 10:eaau5516.

92. Depla E, Van der Aa A, Livingston BD, Crimi C, Allosery K, De Brabandere V, Krakover J, Murthy S, Huang M, Power S, et al. Rational design of a multiepitope vaccine encoding T-lymphocyte epitopes for treatment of chronic hepatitis B virus infections. J Virol. 2008;82:435-50.

93. Nezafat N, Ghasemi Y, Javadi G, Khoshnoud MJ, Omidinia E. A novel multiepitope peptide vaccine against cancer: an in silico approach. J Theor Biol. 2014;349:121-34.

94. Chiuppesi F, Nguyen J, Park S, Contreras H, Kha M, Meng Z, Kaltcheva T, Iniguez A, Martinez J, La Rosa C, et al. Multiantigenic modified vaccinia virus 
Ankara vaccine vectors to elicit potent humoral and cellular immune Reponses against human cytomegalovirus in mice. J Virol. 2018;92:e01012-8.

95. Wu AA, Drake V, Huang HS, Chiu S, Zheng L. Reprogramming the tumor microenvironment: tumor-induced immunosuppressive factors paralyze $T$ cells. Oncoimmunology. 2015;4:e1016700.

96. Sharma P, Hu-Lieskovan S, Wargo JA, Ribas A. Primary, adaptive, and acquired resistance to cancer immunotherapy. Cell. 2017;168:707-23.

97. Haanen J. Converting cold into hot tumors by combining immunotherapies. Cell. 2017;170:1055-6.

98. Liu Z, Ravindranathan R, Kalinski P, Guo ZS, Bartlett DL. Rational combination of oncolytic vaccinia virus and PD-L1 blockade works synergistically to enhance therapeutic efficacy. Nat Commun. 2017;8:14754.

99. Baumeister SH, Freeman GJ, Dranoff G, Sharpe AH. Coinhibitory pathways in immunotherapy for cancer. Annu Rev Immunol. 2016;34:539-73.

100. Topalian SL, Drake CG, Pardoll DM. Immune checkpoint blockade: a common denominator approach to cancer therapy. Cancer Cell. 2015;27: 450-61.

101. Timiryasova TM, Li J, Chen B, Chong D, Langridge WH, Gridley DS, Fodor I. Antitumor effect of vaccinia virus in glioma model. Oncol Res. 1999;11:133-44.

102. McCart JA, Puhlmann M, Lee J, Hu Y, Libutti SK, Alexander HR, Bartlett DL. Complex interactions between the replicating oncolytic effect and the enzyme/prodrug effect of vaccinia-mediated tumor regression. Gene Ther. 2000;7:1217-23.

103. Chan WM, McFadden G. Oncolytic poxviruses. Annu Rev Virol. 2014;1:119-41.

104. Parato KA, Breitbach CJ, Le Boeuf F, Wang J, Storbeck C, Ilkow C, Diallo JS, Falls T, Burns J, Garcia V, et al. The oncolytic poxvirus JX-594 selectively replicates in and destroys cancer cells driven by genetic pathways commonly activated in cancers. Mol Ther. 2012;20:749-58.

105. McCart JA, Ward JM, Lee J, Hu Y, Alexander HR, Libutti SK, Moss B, Bartlett DL. Systemic cancer therapy with a tumor-selective vaccinia virus mutant lacking thymidine kinase and vaccinia growth factor genes. Cancer Res. 2001:61:8751-7.

106. Kirn DH, Wang Y, Le Boeuf F, Bell J, Thorne SH. Targeting of interferon-beta to produce a specific, multi-mechanistic oncolytic vaccinia virus. PLoS Med. 2007:4:e353.

107. Zhang Q, Yu YA, Wang E, Chen N, Danner RL, Munson PJ, Marincola FM Szalay AA. Eradication of solid human breast tumors in nude mice with an intravenously injected light-emitting oncolytic vaccinia virus. Cancer Res. 2007;67:10038-46

108. Smith GL. Vaccinia virus immune evasion. Immunol Lett. 1999;65:55-62.

109. Kirn DH, Wang Y, Liang W, Contag CH, Thorne SH. Enhancing poxvirus oncolytic effects through increased spread and immune evasion. Cancer Res. 2008;68:2071-5.

110. Potts KG, Irwin CR, Favis NA, Pink DB, Vincent KM, Lewis JD, Moore RB, Hitt MM, Evans DH. Deletion of F4L (ribonucleotide reductase) in vaccinia virus produces a selective oncolytic virus and promotes anti-tumor immunity with superior safety in bladder cancer models. EMBO Mol Med. 2017;9:638-54.

111. Mejias-Perez E, Carreno-Fuentes L, Esteban M. Development of a safe and effective vaccinia virus oncolytic vector WR-Delta4 with a set of gene deletions on several viral pathways. Mol Ther Oncolytics. 2018;8:27-40.

112. Burgess HM, Pourchet A, Hajdu CH, Chiriboga L, Frey AB, Mohr I. Targeting poxvirus decapping enzymes and mRNA decay to generate an effective oncolytic virus. Mol Ther Oncolytics. 2018;8:71-81.

113. Ricordel M, Foloppe J, Antoine D, Findeli A, Kempf J, Cordier P, Gerbaud A Grellier B, Lusky M, Quemeneur E, et al. Vaccinia virus shuffling: deW5, a novel chimeric poxvirus with improved oncolytic potency. Cancers (Basel). 2018;10:231.

114. Choi AH, O'Leary MP, Chaurasiya S, Lu J, Kim SI, Fong Y, Chen NG. Novel chimeric parapoxvirus CF189 as an oncolytic immunotherapy in triplenegative breast cancer. Surgery. 2018;163:336-42.

115. Yoo SY, Jeong SN, Kang DH, Heo J. Evolutionary cancer-favoring engineered vaccinia virus for metastatic hepatocellular carcinoma. Oncotarget. 2017;8: 71489-99.

116. Tesniere A, Apetoh L, Ghiringhelli F, Joza N, Panaretakis T, Kepp O, Schlemmer F, Zitvogel L, Kroemer G. Immunogenic cancer cell death: a keylock paradigm. Curr Opin Immunol. 2008;20:504-11.

117. Guo ZS, Liu Z, Bartlett DL. Oncolytic immunotherapy: dying the right way is a key to eliciting potent antitumor immunity. Front Oncol. 2014;4:74.

118. Kepp O, Senovilla L, Vitale I, Vacchelli E, Adjemian S, Agostinis P, Apetoh L, Aranda F, Barnaba V, Bloy N, et al. Consensus quidelines for the detection of immunogenic cell death. Oncoimmunology. 2014;3:e955691.
119. Berwin B, Reed RC, Nicchitta CV. Virally induced lytic cell death elicits the release of immunogenic GRP94/gp96. J Biol Chem. 2001;276:21083-8.

120. John LB, Howland $\amalg$, Flynn JK, West AC, Devaud C, Duong CP, Stewart TJ, Westwood JA, Guo ZS, Bartlett DL, et al. Oncolytic virus and anti-4-1BB combination therapy elicits strong antitumor immunity against established cancer. Cancer Res. 2012;72:1651-60.

121. Fend L, Yamazaki T, Remy C, Fahrner C, Gantzer M, Nourtier V, Preville X, Quemeneur E, Kepp O, Adam J, et al. Immune checkpoint blockade, immunogenic chemotherapy or IFN-alpha blockade boost the local and abscopal effects of oncolytic virotherapy. Cancer Res. 2017;77:4146-57.

122. Whilding LM, Archibald KM, Kulbe H, Balkwill FR, Oberg D, McNeish IA. Vaccinia virus induces programmed necrosis in ovarian cancer cells. Mol Ther. 2013;21:2074-86.

123. O'Leary MP, Warner SG, Kim SI, Chaurasiya S, Lu J, Choi AH, Park AK, Woo Y, Fong Y, Chen NG. A novel oncolytic chimeric orthopoxvirus encoding luciferase enables real-time view of colorectal cancer cell infection. Mol Ther Oncolytics. 2018:9:13-21.

124. Tappe KA, Budida R, Stankov MV, Frenz T, Shah H, Volz A, Sutter G, Kalinke $U$, Behrens GMN. Immunogenic cell death of dendritic cells following modified vaccinia virus Ankara infection enhances CD8(+) T cell proliferation. Eur J Immunol. 2018;48:2042-54.

125. Kim JH, Oh JY, Park BH, Lee DE, Kim JS, Park HE, Roh MS, Je JE, Yoon JH, Thorne SH, et al. Systemic armed oncolytic and immunologic therapy for cancer with JX-594, a targeted poxvirus expressing GM-CSF. Mol Ther. 2006; 14:361-70.

126. Thorne SH, Hwang TH, O'Gorman WE, Bartlett DL, Sei S, Kanji F, Brown C, Werier J, Cho JH, Lee DE, et al. Rational strain selection and engineering creates a broad-spectrum, systemically effective oncolytic poxvirus, JX-963. J Clin Invest. 2007;117:3350-8.

127. Deng L, Fan J, Guo M, Huang B. Oncolytic and immunologic cancer therapy with GM-CSF-armed vaccinia virus of Tian Tan strain Guang9. Cancer Lett. 2016:372:251-7.

128. Chard LS, Maniati E, Wang P, Zhang Z, Gao D, Wang J, Cao F, Ahmed J, El Khouri $M$, Hughes J, et al. A vaccinia virus armed with interleukin-10 is a promising therapeutic agent for treatment of murine pancreatic cancer. Clin Cancer Res. 2015;21:405-16.

129. Lv C, Su Q, Liang Y, Hu J, Yuan S. Oncolytic vaccine virus harbouring the IL24 gene suppresses the growth of lung cancer by inducing apoptosis. Biochem Biophys Res Commun. 2016;476:21-8.

130. Liu Z, Ravindranathan R, Li J, Kalinski P, Guo ZS, Bartlett DL. CXCL11-armed oncolytic poxvirus elicits potent antitumor immunity and shows enhanced therapeutic efficacy. Oncoimmunology. 2016;5:e1091554.

131. Kowalsky SJ, Liu Z, Feist M, Berkey SE, Ma C, Ravindranathan R, Dai E, Roy EJ, Guo ZS, Bartlett DL. Superagonist IL-15-armed oncolytic virus elicits potent antitumor immunity and therapy that are enhanced with PD-1 blockade. Mol Ther. 2018;26:2476-86

132. Liu Z, Ge Y, Wang H, Ma C, Feist M, Ju S, Guo ZS, Bartlett DL. Modifying the cancer-immune set point using vaccinia virus expressing re-designed interleukin-2. Nat Commun. 2018:9:4682

133. Yu F, Wang X, Guo ZS, Bartlett DL, Gottschalk SM, Song XT. T-cell engagerarmed oncolytic vaccinia virus significantly enhances antitumor therapy. Mol Ther. 2014;22:102-11.

134. Zou W. Immunosuppressive networks in the tumour environment and their therapeutic relevance. Nat Rev Cancer. 2005;5:263-74.

135. Devaud C, John LB, Westwood JA, Darcy PK, Kershaw MH. Immune modulation of the tumor microenvironment for enhancing cancer immunotherapy. Oncoimmunology. 2013;2:e25961.

136. Ribas A, Dummer R, Puzanov I, VanderWalde A, Andtbacka RHI, Michielin O, Olszanski AJ, Malvehy J, Cebon J, Fernandez E, et al. Oncolytic virotherapy promotes intratumoral T cell infiltration and improves anti-PD-1 immunotherapy. Cell. 2017;170:1109-19 e1110.

137. Gujar S, Pol JG, Kroemer G. Heating it up: oncolytic viruses make tumors 'hot' and suitable for checkpoint blockade immunotherapies. Oncoimmunology. 2018;7:e1442169.

138. Hou W, Sampath P, Rojas JJ, Thorne SH. Oncolytic virus-mediated targeting of PGE2 in the tumor alters the immune status and sensitizes established and resistant tumors to immunotherapy. Cancer Cell. 2016; 30:108-19.

139. Marchini A, Scott EM, Rommelaere J. Overcoming barriers in oncolytic virotherapy with HDAC inhibitors and immune checkpoint blockade. Viruses. 2016;8:E9. 
140. Nguyen TL, Abdelbary H, Arguello M, Breitbach C, Leveille S, Diallo JS, Yasmeen A, Bismar TA, Kirn D, Falls T, et al. Chemical targeting of the innate antiviral response by histone deacetylase inhibitors renders refractory cancers sensitive to viral oncolysis. Proc Natl Acad Sci U S A. 2008:105: 14981-6.

141. MacTavish H, Diallo JS, Huang B, Stanford M, Le Boeuf F, De Silva N, Cox J, Simmons JG, Guimond T, Falls T, et al. Enhancement of vaccinia virus based oncolysis with histone deacetylase inhibitors. PLoS One. 2010;5:e14462.

142. Francis L, Guo ZS, Liu Z, Ravindranathan R, Urban JA, Sathaiah M, Magge D, Kalinski P, Bartlett DL. Modulation of chemokines in the tumor microenvironment enhances oncolytic virotherapy for colorectal cancer. Oncotarget. 2016;7:22174-85.

143. Muthuswamy R, Berk E, Junecko BF, Zeh HJ, Zureikat AH, Normolle D, Luong TM, Reinhart TA, Bartlett DL, Kalinski P. NF-kappaB hyperactivation in tumor tissues allows tumor-selective reprogramming of the chemokine microenvironment to enhance the recruitment of cytolytic T effector cells. Cancer Res. 2012;72:3735-43.

144. Kim M, Nitschke M, Sennino B, Murer P, Schriver BJ, Bell A, Subramanian A, McDonald CE, Wang J, Cha $\mathrm{H}$, et al. Amplification of oncolytic vaccinia virus widespread tumor cell killing by Sunitinib through multiple mechanisms. Cancer Res. 2018;78:922-37.

145. Smith GL, Vanderplasschen A, Law M. The formation and function of extracellular enveloped vaccinia virus. J Gen Virol. 2002:83:2915-31.

146. Locker JK, Kuehn A, Schleich S, Rutter G, Hohenberg H, Wepf R, Griffiths G. Entry of the two infectious forms of vaccinia virus at the plasma membane is signaling-dependent for the IMV but not the EEV. Mol Biol Cell. 2000;11: 2497-511.

147. Ichihashi $Y$. Extracellular enveloped vaccinia virus escapes neutralization. Virology. 1996;217:478-85.

148. Vanderplasschen A, Mathew E, Hollinshead M, Sim RB, Smith GL. Extracellular enveloped vaccinia virus is resistant to complement because of incorporation of host complement control proteins into its envelope. Proc Natl Acad Sci U S A. 1998;95:7544-9.

149. Breiman A, Smith GL. Vaccinia virus B5 protein affects the glycosylation, localization and stability of the A34 protein. J Gen Virol. 2010:91:1823-7.

150. McIntosh AA, Smith GL. Vaccinia virus glycoprotein A34R is required for infectivity of extracellular enveloped virus. J Virol. 1996;70:272-81.

151. Ferguson MS, Lemoine NR, Wang Y. Systemic delivery of oncolytic viruses: hopes and hurdles. Adv Virol. 2012;2012:805629.

152. Seymour LW, Fisher KD. Oncolytic viruses: finally delivering. Br J Cancer. 2016;114:357-61.

153. Kulu Y, Dorfman JD, Kuruppu D, Fuchs BC, Goodwin JM, Fujii T, Kuroda T, Lanuti M, Tanabe KK. Comparison of intravenous versus intraperitoneal administration of oncolytic herpes simplex virus 1 for peritoneal carcinomatosis in mice. Cancer Gene Ther. 2009;16:291-7.

154. Andtbacka RH, Kaufman HL, Collichio F, Amatruda T, Senzer N, Chesney J, Delman KA, Spitler LE, Puzanov I, Agarwala SS, et al. Talimogene laherparepvec improves durable response rate in patients with advanced melanoma. J Clin Oncol. 2015;33:2780-8.

155. Breitbach CJ, Burke J, Jonker D, Stephenson J, Haas AR, Chow LQ, Nieva J, Hwang TH, Moon A, Patt R, et al. Intravenous delivery of a multimechanistic cancer-targeted oncolytic poxvirus in humans. Nature. 2011 477:99-102.

156. Park SH, Breitbach CJ, Lee J, Park JO, Lim HY, Kang WK, Moon A, Mun JH, Sommermann EM, Maruri Avidal $L$, et al. Phase 1b trial of biweekly intravenous Pexa-Vec (JX-594), an oncolytic and immunotherapeutic vaccinia virus in colorectal cancer. Mol Ther. 2015;23:1532-40.

157. Downs-Canner S, Guo ZS, Ravindranathan R, Breitbach CJ, O'Malley ME, Jones HL, Moon A, McCart JA, Shuai Y, Zeh HJ, et al. Phase 1 study of intravenous oncolytic poxvirus (VvDD) in patients with advanced solid cancers. Mol Ther. 2016;24:1492-501.

158. Mell LK, Brumund KT, Daniels GA, Advani SJ, Zakeri K, Wright ME, Onyeama SJ, Weisman RA, Sanghvi PR, Martin PJ, et al. Phase I trial of intravenous oncolytic vaccinia virus (GL-ONC1) with cisplatin and radiotherapy in patients with locoregionally advanced head and neck carcinoma. Clin Cancer Res. 2017;23:5696-702.

159. Liu TC, Hwang T, Park BH, Bell J, Kirn DH. The targeted oncolytic poxvirus JX-594 demonstrates antitumoral, antivascular, and anti-HBV activities in patients with hepatocellular carcinoma. Mol Ther. 2008;16: 1637-42.
160. Breitbach CJ, Arulanandam R, De Silva N, Thorne SH, Patt R, Daneshmand M, Moon A, Ilkow C, Burke J, Hwang TH, et al. Oncolytic vaccinia virus disrupts tumor-associated vasculature in humans. Cancer Res. 2013;73:1265-75.

161. Arulanandam R, Batenchuk C, Angarita FA, Ottolino-Perry K, Cousineau S, Mottashed A, Burgess E, Falls TJ, De Silva N, Tsang J, et al. VEGF-mediated induction of PRD1-BF1/Blimp1 expression sensitizes tumor vasculature to oncolytic virus infection. Cancer Cell. 2015;28:210-24.

162. Heo J, Reid T, Ruo L, Breitbach CJ, Rose S, Bloomston M, Cho M, Lim $\mathrm{HY}$, Chung HC, Kim CW, et al. Randomized dose-finding clinical trial of oncolytic immunotherapeutic vaccinia JX-594 in liver cancer. Nat Med. 2013;19:329-36.

163. Kim MK, Breitbach CJ, Moon A, Heo J, Lee YK, Cho M, Lee JW, Kim SG, Kang $\mathrm{DH}$, Bell JC, et al. Oncolytic and immunotherapeutic vaccinia induces antibody-mediated complement-dependent cancer cell lysis in humans. Sci Transl Med. 2013;5:185ra163.

164. Lauer UM, Schell M, Beil J, Berchtold S, Koppenhofer U, Glatzle J, Konigsrainer A, Mohle R, Nann D, Fend F, et al. Phase I study of oncolytic vaccinia virus GL-ONC1 in patients with peritoneal carcinomatosis. Clin Cancer Res. 2018:24:4388-98.

165. Zeh HJ, Downs-Canner S, McCart JA, Guo ZS, Rao UN, Ramalingam L, Thorne SH, Jones HL, Kalinski P, Wieckowski E, et al. First-in-man study of western reserve strain oncolytic vaccinia virus: safety, systemic spread, and antitumor activity. Mol Ther. 2015;23:202-14.

166. Lawrence MS, Stojanov P, Polak P, Kryukov GV, Cibulskis K, Sivachenko A, Carter SL, Stewart C, Mermel CH, Roberts SA, et al. Mutational heterogeneity in cancer and the search for new cancer-associated genes. Nature. 2013;499: 214-8.

167. Luksza M, Riaz N, Makarov V, Balachandran VP, Hellmann MD, Solovyov A, Rizvi NA, Merghoub T, Levine AJ, Chan TA, et al. A neoantigen fitness model predicts tumour response to checkpoint blockade immunotherapy. Nature. 2017:551:517-20.

168. Melief CJ, van Hall T, Arens R, Ossendorp F, van der Burg SH. Therapeutic cancer vaccines. J Clin Invest. 2015;125:3401-12.

169. Maeng $H$, Terabe $M$, Berzofsky JA. Cancer vaccines: translation from mice to human clinical trials. Curr Opin Immunol. 2018;51:111-22.

170. Twumasi-Boateng K, Pettigrew JL, Kwok YYE, Bell JC, Nelson BH. Oncolytic viruses as engineering platforms for combination immunotherapy. Nat Rev Cancer. 2018;18:419-32.

171. Guo ZS, Liu Z, Kowalsky S, Feist M, Kalinski P, Lu B, Storkus WJ, Bartlett DL. Oncolytic immunotherapy: conceptual evolution, current strategies, and future perspectives. Front Immunol. 2017:8:555.

172. Forbes NS, Coffin RS, Deng L, Evgin L, Fiering S, Giacalone M, Gravekamp C, Gulley JL, Gunn H, Hoffman RM, et al. White paper on microbial anti-cancer therapy and prevention. J Immunother Cancer. 2018;6:78.

173. Spitzer MH, Carmi Y, Reticker-Flynn NE, Kwek SS, Madhireddy D, Martins MM, Gherardini PF, Prestwood TR, Chabon J, Bendall SC, et al. Systemic immunity is required for effective cancer immunotherapy. Cell. 2017;168: 487-502 e415.

174. Grosenbach DW, Hruby DE. Biology of vaccinia virus acylproteins. Front Biosci. 1998;3:d354-64

175. Clark RH, Kenyon JC, Bartlett NW, Tscharke DC, Smith GL. Deletion of gene A41L enhances vaccinia virus immunogenicity and vaccine efficacy. J Gen Virol. 2006:87:29-38.

176. Reading PC, Moore JB, Smith GL. Steroid hormone synthesis by vaccinia virus suppresses the inflammatory response to infection. J Exp Med. 2003; 197:1269-78.

177. Alcami A, Khanna A, Paul NL, Smith GL. Vaccinia virus strains Lister, USSR and Evans express soluble and cell-surface tumour necrosis factor receptors. J Gen Virol. 1999:80:949-59.

178. Alcami A, Smith GL. Vaccinia, cowpox, and camelpox viruses encode soluble gamma interferon receptors with novel broad species specificity. J Virol. 1995:69:4633-9.

179. Kettle S, Alcami A, Khanna A, Ehret R, Jassoy C, Smith GL. Vaccinia virus serpin B13R (SPI-2) inhibits interleukin-1 beta-converting enzyme and protects virus-infected cells from TNF- and Fas-mediated apoptosis, but does not prevent IL-1beta-induced fever. J Gen Virol. 1997;78:677-85.

180. Colamonici OR, Domanski P, Sweitzer SM, Larner A, Buller RM. Vaccinia virus B18R gene encodes a type I interferon-binding protein that blocks interferon alpha transmembrane signaling. J Biol Chem. 1995;270:15974-8.

181. Jha P, Kotwal GJ. Vaccinia complement control protein: multi-functional protein and a potential wonder drug. J Biosci. 2003;28:265-71. 
182. Girgis NM, Dehaven BC, Xiao Y, Alexander E, Viner KM, Isaacs SN. The vaccinia virus complement control protein modulates adaptive immune responses during infection. J Virol. 2011;85:2547-56.

183. Stuart JH, Sumner RP, Lu Y, Snowden JS, Smith GL. Vaccinia virus protein C6 inhibits type I IFN signalling in the nucleus and binds to the transactivation domain of STAT2. PLoS Pathog. 2016;12:e1005955.

184. Meng X, Jiang C, Arsenio J, Dick K, Cao J, Xiang Y. Vaccinia virus K1L and C7L inhibit antiviral activities induced by type I interferons. J Virol. 2009;83: 10627-36.

185. Meng X, Schoggins J, Rose L, Cao J, Ploss A, Rice CM, Xiang Y. C7L family of poxvirus host range genes inhibits antiviral activities induced by type I interferons and interferon regulatory factor 1. J Virol. 2012;86:4538-47.

186. Symons JA, Adams E, Tscharke DC, Reading PC, Waldmann H, Smith GL. The vaccinia virus $\mathrm{C} 12 \mathrm{~L}$ protein inhibits mouse $\mathrm{IL}-18$ and promotes virus virulence in the murine intranasal model. J Gen Virol. 2002:83:2833-44.

187. Guerra S, Caceres A, Knobeloch KP, Horak I, Esteban M. Vaccinia virus E3 protein prevents the antiviral action of ISG15. PLoS Pathog. 2008:4:e1000096.

188. Gerlic M, Faustin B, Postigo A, Yu EC, Proell M, Gombosuren N, Krajewska M, Flynn R, Croft M, Way M, et al. Vaccinia virus F1L protein promotes virulence by inhibiting inflammasome activation. Proc Natl Acad Sci U S A. 2013;110: 7808-13.

189. Davies MV, Chang HW, Jacobs BL, Kaufman RJ. The E3L and K3L vaccinia virus gene products stimulate translation through inhibition of the doublestranded RNA-dependent protein kinase by different mechanisms. J Virol. 1993;67:1688-92.

190. Carroll K, Elroy-Stein O, Moss B, Jagus R. Recombinant vaccinia virus K3L gene product prevents activation of double-stranded RNA-dependent, initiation factor 2 alpha-specific protein kinase. J Biol Chem. 1993;268: 12837-42.

191. Benfield CT, Ren H, Lucas SJ, Bahsoun B, Smith GL. Vaccinia virus protein K7 is a virulence factor that alters the acute immune response to infection. J Gen Virol. 2013;94:1647-57.

192. Teferi WM, Desaulniers MA, Noyce RS, Shenouda M, Umer B, Evans DH. The vaccinia virus $\mathrm{K} 7$ protein promotes histone methylation associated with heterochromatin formation. PLoS One. 2017;12:e0173056.

193. Ryerson MR, Richards MM, Kvansakul M, Hawkins CJ, Shisler JL. Vaccinia virus encodes a novel inhibitor of apoptosis that associates with the apoptosome. J Virol. 2017;91:e01385-17.

194. Cooray S, Bahar MW, Abrescia NG, McVey CE, Bartlett NW, Chen RA, Stuart $\mathrm{DI}$, Grimes JM, Smith GL. Functional and structural studies of the vaccinia virus virulence factor N1 reveal a Bcl-2-like anti-apoptotic protein. J Gen Virol. 2007:88:1656-66.

195. Harrop R, Shingler WH, McDonald M, Treasure P, Amato RJ, Hawkins RE, Kaufman HL, de Belin J, Kelleher M, Goonewardena M, et al. MVA-5T4induced immune responses are an early marker of efficacy in renal cancer patients. Cancer Immunol Immunother. 2011;60:829-37.

196. Adamina M, Rosenthal R, Weber WP, Frey DM, Viehl CT, Bolli M, Huegli RW, Jacob AL, Heberer M, Oertli D, et al. Intranodal immunization with a vaccinia virus encoding multiple antigenic epitopes and costimulatory molecules in metastatic melanoma. Mol Ther. 2010;18:651-9.

197. Heery CR, Palena C, McMahon S, Donahue RN, Lepone LM, Grenga I, Dirmeier U, Cordes L, Marte J, Dahut W, et al. Phase I study of a poxviral TRICOM-based vaccine directed against the transcription factor brachyury. Clin Cancer Res. 2017;23:6833-45.

198. Wilkinson MJ, Smith HG, McEntee G, Kyula-Currie J, Pencavel TD, Mansfield DC, Khan AA, Roulstone V, Hayes AJ, Harrington KJ. Oncolytic vaccinia virus combined with radiotherapy induces apoptotic cell death in sarcoma cells by down-regulating the inhibitors of apoptosis. Oncotarget. 2016;7:81208-22.

\section{Ready to submit your research? Choose BMC and benefit from:}

- fast, convenient online submission

- thorough peer review by experienced researchers in your field

- rapid publication on acceptance

- support for research data, including large and complex data types

- gold Open Access which fosters wider collaboration and increased citations

- maximum visibility for your research: over $100 \mathrm{M}$ website views per year

At BMC, research is always in progress.

Learn more biomedcentral.com/submissions 